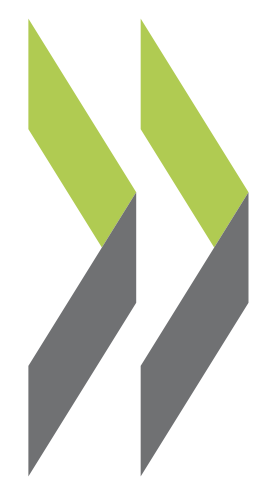

OECD Social, Employment and Migration Working Papers No. 149

\title{
A Bird's Eye View of Gender Differences in Education in OECD Countries
}

\section{Angelica Salvi del Pero,}

\section{Alexandra Bytchkova}


Organisation de Coopération et de Développement Économiques

Organisation for Economic Co-operation and Development

05-Sep-2013

DIRECTORATE FOR EMPLOYMENT, LABOUR AND SOCIAL AFFAIRS

English - Or. English

EMPLOYMENT, LABOUR AND SOCIAL AFFAIRS COMMITTEE

OECD SOCIAL, EMPLOYMENT AND MIGRATION WORKING PAPERS No. 149

A Bird's Eye View of Gender Differences in Education in OECD Countries

Angelica Salvi Del Pero and Alexandra Bytchkova

JEL classification: I21, I23, I28, J16

Keywords: gender, education attainment, college major, student performance, PISA, attitudes

All Social, Employment and Migration Working Papers are now available through the OECD website at www.oecd.org/els/workingpapers

JT03343971

Complete document available on OLIS in its original format

This document and any map included herein are without prejudice to the status of or sovereignty over any territory, to the delimitation of international frontiers and boundaries and to the name of any territory, city or area. 


\title{
DIRECTORATE FOR EMPLOYMENT, LABOUR AND SOCIAL AFFAIRS
}

www.oecd.org/els

\section{OECD SOCIAL, EMPLOYMENT AND MIGRATION WORKING PAPERS}

\author{
www.oecd.org/els/workingpapers
}

This series is designed to make available to a wider readership selected labour market, social policy and migration studies prepared for use within the OECD. Authorship is usually collective, but principal writers are named. The papers are generally available only in their original language - English or French - with a summary in the other.

Comment on the series is welcome, and should be sent to the Directorate for Employment, Labour and Social Affairs, 2, rue André-Pascal, 75775 PARIS CEDEX 16, France.

The opinions expressed and arguments employed here are the responsibility of the author(s) and do not necessarily reflect those of the OECD.

Applications for permission to reproduce or translate all or part of this material should be made to:

\author{
Head of Publications Service \\ OECD \\ 2, rue André-Pascal \\ 75775 Paris, CEDEX 16 \\ France
}

Copyright OECD 2010 
DELSA/ELSA/WD/SEM(2013)4

\section{ACKNOWLEDGEMENTS}

The authors gratefully acknowledge the comments provided by Willem Adema, Francesca Borgonovi and Lucie Davoine. This publication has been produced with the assistance of the European Union. The contents of this publication can in no way be taken to reflect the views of the European Union. The views expressed in this paper are those of the author and do not necessarily reflect those of the OECD or its member countries. 


\section{SUMMARY}

This paper presents an overview of gender differences in education outcomes in OECD countries. A rich set of indicators describes the improvement of educational attainment among women over the past decades, and various dimensions of male under-performance in education. Possible explanatory factors include incentives provided by changing employment opportunities for women, demographic trends, as well as the higher sensitivity of boys to disadvantaged socio-economic backgrounds. Gender differences in field of study and in performance by subject are found to be related to attitudes and self-perceptions towards academic subjects, which are in turn influenced by social norms. A number of policy options to address gender gaps are presented in the final section of the paper.

\section{RÉSUMÉ}

Ce document présente un aperçu des différences entre garçons et filles dans les résultats scolaires des pays de l'OCDE. Les indicateurs utilisés décrivent l'amélioration du niveau d'instruction des femmes au cours des dernières décennies et les différents domaines dans lesquels les garçons obtiennent des résultats inférieurs par rapport aux filles. Parmi les explications avancées figurent les politiques encourageant les opportunités d'emploi pour les femmes, les tendances démographiques ainsi que la vulnérabilité accrue des garçons issus de milieux socio-économiques défavorisés. Les différences entre hommes et femmes dans le domaine des études et dans les résultats scolaires par discipline tiennent aux mentalités et à l'autoperception des disciplines, et sont elles-mêmes influencées par les normes sociales. La dernière section du document présente un certain nombre de mesures pouvant combler les disparités entre hommes et femmes. 


\section{TABLE OF CONTENTS}

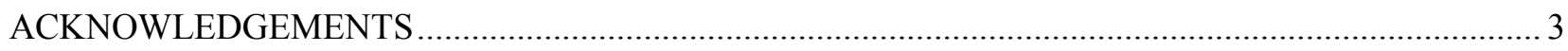

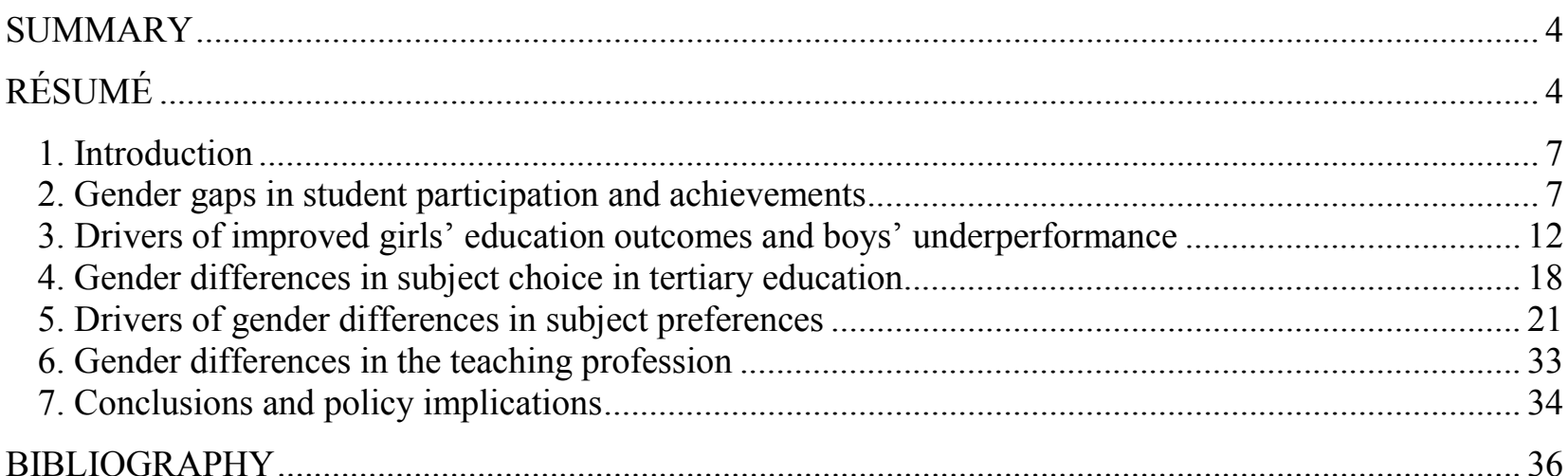

\section{Tables}

Table 1. Average years of completed education, men and women aged 25-64 8

\section{Figures}

Figure 1. Proportion of men and women that attained at least upper secondary education, by age group

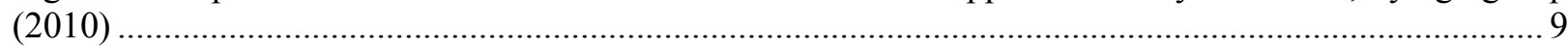

Figure 2. Proportion of men and women that attained tertiary education, by age group (2010)............. 10

Figure 3. Trends in entry rates at tertiary level, by gender (2005-2010) ........................................... 11

Figure 4. Entry rates in tertiary type-A education, by gender (2010) .................................................. 11

Figure 5. Proportion of women among entrants and graduates in tertiary education (2010) .................. 12

Figure 6. Percentage of qualifications awarded to women at different tertiary levels (2010)................. 12

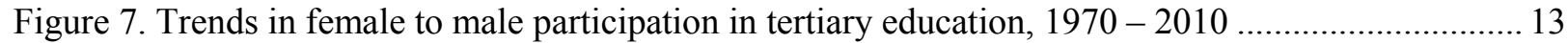

Figure 8. Women's participation in the labour force and participation in tertiary education, OECD

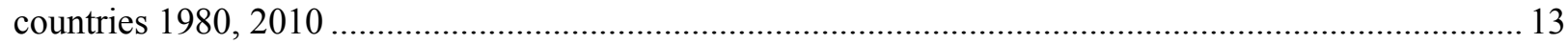

Figure 9. Employment earnings premium, 2010 or latest available year .............................................. 14

Figure 10. Differences in earnings between women and men, 2009................................................ 14

Figure 11. Age at first birth and women's participation in tertiary education, OECD countries, 2009 ... 15

Figure 12. Employment rates by educational attainment and gender, 25-64 year-olds 2010 ................ 15

Figure 13. Enrolment rate in education for population aged 15 to 19 , by gender $(2010)$......................... 16

Figure 14. Successful completion of upper secondary programmes, by gender (2010)........................ 17

Figure 15. Proportion of student who report having repeated a grade in secondary education (2009).... 18

Figure 16. Proportion of students expecting to complete a university degree, by gender at age $15 \ldots \ldots . . .18$

Figure 17. Proportion of degrees awarded to women, selected fields of study (2010) .......................... 19

Figure 18. Change in the proportion of tertiary degrees awarded to women by field, 2010-2000........... 20 
Figure 19. Trends in number of graduates in tertiary education by field of education, OECD average

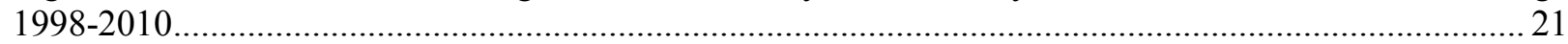

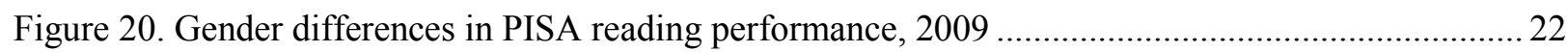

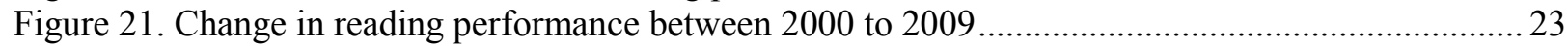

Figure 22. PIRLS reading performance by gender in 4th and 8th grade............................................. 23

Figure 23. The role of engagement in reading and approaches to learning in compounding gender

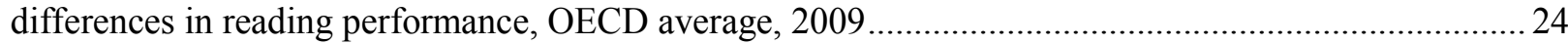

Figure 24. Gender differences in PISA mathematics performance, 2009 ........................................... 25

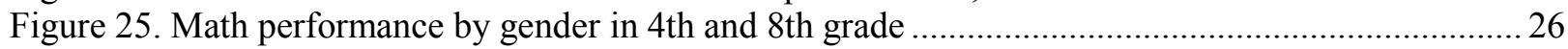

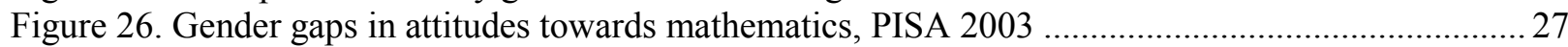

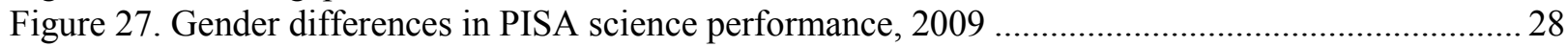

Figure 28. Gender gap in PISA score points by performance level, 2009 .........................................28

Figure 29. Women in computing vs. maths performance and maths self-concept...................................29

Figure 30. Percentage of 15-year-old boys and girls planning a career in engineering and computing.... 31

Figure 31. Percentage of 15-year-old boys and girls planning a career in health services....................... 31

Figure 32. Men and women who graduated in the same field often make different occupational choices32

Figure 33. Proportion of women among teachers, at various level of education .................................... 33 


\section{Introduction}

1. Over the past half century, OECD and EU countries have made significant investment in human capital, achieving significant increases in the educational attainment of both men and women. Progress in educational attainment among women and men has brought along improvements in labour productivity, labour force participation, as well as child mortality, fertility and health. The more equal gender distribution of education has furthered these positive effects; Thévenon et al., (2012), find that increases in educational attainment have accounted for about 50\% of GDP growth in OECD countries between 1960 and 2008, and about half of this increase was due to improvements in women's educational attainment compared to men's.

2. Nevertheless, educational outcomes still vary widely across and within countries. This variation exists for many reasons, ranging from the resources given to the educational system, the educational practices followed by countries, differences in educational opportunities for students from disadvantaged socio-economic background, and differences in learning resources outside of the formal educational system. Educational outcomes also vary by gender, with some stylized facts common to all countries. Compared to girls, boys have become more likely to underperform in secondary education and less likely to complete higher education degrees. At the same time, women remain significantly under-represented among graduates in fields such as engineering or technology while men are under-represented in fields such as education and health and welfare (OECD, 2012a).

3. These gendered patterns raise concern for policy makers for a number of reasons. To the extent that the observed gender gaps are the result of social constructs both inside and outside the education systems and not the result of intrinsic differences in preferences and ability between men and women, they imply an under-utilization and misallocation of talent, which limits economic growth. In addition, there are costs at the individual level. Under-performance in education hinders employment opportunities and increases the risk of poverty and social exclusion; horizontal segregation in the field of study contributes to occupational segregation, which hinders employment opportunities and significantly contributes to gender gaps in earnings.

4. The paper is organised as follows. Section 2 provides a comprehensive review of the main dimension of gender gaps in participation and achievements in education, in a cross-country and acrosstime perspective; section 3 analyses the main drivers of these trends; section 4 describes gender segregation in tertiary education; and an analysis of the potential drivers of gender gaps in field of study is provided in section 5. Section 6 offers an overview of gender differences in the teaching profession. Section 7 concludes with policy implications.

\section{Gender gaps in student participation and achievements}

5. Over the past decades, in the OECD and the EU, educational attainment among women has increased significantly and more rapidly than among men (Table 1). As a result in most of these countries gender gaps in educational attainment have closed or even reversed and women nowadays often have higher educational attainment than men. In OECD countries the average number of years of completed education among the working-age population has increased from 6.3 to 11.3 for men and from 5.6 to 11.3 for women. In most countries the "takeover" happened between 1990 and 2010. 
Table 1. Average years of completed education, men and women aged 25-64

\begin{tabular}{|c|c|c|c|c|c|c|c|c|}
\hline & \multicolumn{2}{|c|}{1950} & \multicolumn{2}{|c|}{1970} & \multicolumn{2}{|c|}{1990} & \multicolumn{2}{|c|}{2010} \\
\hline & Men & Women & Men & Women & Men & Women & Men & Women \\
\hline Australia & 9.2 & 8.2 & 10.9 & 9.7 & 11.8 & 12.0 & 11.5 & 12.7 \\
\hline Austria & 4.1 & 3.4 & 7.6 & 5.3 & 9.4 & 7.6 & 10.9 & 9.7 \\
\hline Belgium & 6.7 & 6.1 & 7.7 & 7.0 & 9.9 & 9.6 & 11.1 & 11.3 \\
\hline Canada & 7.4 & 7.8 & 9.1 & 8.9 & 10.9 & 10.7 & 12.6 & 12.8 \\
\hline Chile & 5.0 & 4.6 & 6.1 & 5.7 & 8.4 & 8.3 & 10.2 & 10.1 \\
\hline Czech Republic & 8.7 & 7.7 & 10.9 & 9.0 & 11.8 & 11.2 & 12.7 & 12.5 \\
\hline Denmark & 8.0 & 6.9 & 9.1 & 7.9 & 10.5 & 9.8 & 10.6 & 10.5 \\
\hline Estonia & 6.8 & 6.3 & 7.9 & 7.6 & 9.7 & 10.2 & 12.0 & 12.8 \\
\hline Finland & 5.4 & 5.4 & 7.0 & 6.9 & 9.3 & 9.1 & 10.8 & 11.4 \\
\hline France & 4.8 & 4.0 & 5.5 & 4.9 & 8.2 & 7.7 & 11.2 & 11.0 \\
\hline Germany & 5.4 & 4.7 & 5.8 & 5.2 & 9.0 & 8.0 & 12.8 & 12.4 \\
\hline Greece & 5.2 & 3.1 & 7.2 & 5.7 & 9.2 & 8.1 & 11.3 & 11.3 \\
\hline Hungary & 7.3 & 6.8 & 8.3 & 7.8 & 9.9 & 9.1 & 12.0 & 12.0 \\
\hline Iceland & 5.6 & 5.4 & 6.9 & 6.7 & 8.7 & 9.2 & 10.6 & 11.4 \\
\hline Ireland* & 7.6 & 7.8 & 8.7 & 8.7 & 11.0 & 11.1 & 11.8 & 12.2 \\
\hline Israel & 8.3 & 6.5 & 9.1 & 7.7 & 11.5 & 11.1 & 12.0 & 12.4 \\
\hline Italy & 4.7 & 3.9 & 5.9 & 5.1 & 8.4 & 7.7 & 10.6 & 10.6 \\
\hline Japan & 6.9 & 5.8 & 8.4 & 7.2 & 10.9 & 10.1 & 12.4 & 12.5 \\
\hline Korea & 5.3 & 3.1 & 7.2 & 4.4 & 10.7 & 8.0 & 12.6 & 12.2 \\
\hline Luxembourg & 7.0 & 6.1 & 8.5 & 7.1 & 9.8 & 8.9 & 10.5 & 10.3 \\
\hline Mexico & 2.7 & 2.1 & 3.5 & 2.8 & 6.3 & 5.5 & 9.3 & 8.7 \\
\hline Netherlands & 6.5 & 6.2 & 8.6 & 8.0 & 10.9 & 10.2 & 11.6 & 11.3 \\
\hline New Zealand & 9.5 & 9.4 & 11.2 & 10.9 & 12.2 & 11.7 & 12.8 & 12.9 \\
\hline Norway & 7.8 & 7.6 & 9.1 & 8.3 & 11.7 & 11.4 & 12.6 & 12.9 \\
\hline Poland & 5.5 & 4.8 & 7.5 & 6.8 & 9.0 & 8.9 & 10.0 & 10.5 \\
\hline Portugal & 2.7 & 2.2 & 4.7 & 2.9 & 7.4 & 6.6 & 8.4 & 8.8 \\
\hline Slovak Republic & 8.8 & 7.7 & 10.7 & 9.1 & 11.3 & 10.7 & 11.5 & 11.8 \\
\hline Slovenia & 6.9 & 5.2 & 8.6 & 7.1 & 11.3 & 10.9 & 11.9 & 12.1 \\
\hline Spain & 2.9 & 2.2 & 4.2 & 3.3 & 7.3 & 6.6 & 10.9 & 11.1 \\
\hline Sweden & 6.8 & 6.5 & 8.1 & 7.7 & 10.7 & 10.9 & 11.9 & 12.4 \\
\hline Switzerland & 7.8 & 6.9 & 9.2 & 8.1 & 11.3 & 9.7 & 11.3 & 10.3 \\
\hline Turkey & 1.6 & 0.5 & 3.1 & 1.3 & 6.0 & 3.6 & 7.8 & 5.9 \\
\hline United Kingdom & 5.6 & 5.9 & 7.3 & 7.2 & 8.1 & 8.4 & 9.4 & 10.3 \\
\hline United States & 8.4 & 8.6 & 11.1 & 11.0 & 12.8 & 12.8 & 13.3 & 13.5 \\
\hline OECD average & 6.3 & 5.6 & 7.8 & 6.9 & 9.9 & 9.3 & 11.3 & 11.3 \\
\hline
\end{tabular}

Note: highlighted cells indicate countries for which women's average educational attainment among women is higher than men's in a given year. *The statistical data for Israel are supplied by and under the responsibility of the relevant Israeli authorities. The use of such data by the OECD is without prejudice to the status of the Golan Heights, East Jerusalem and Israeli settlements in the West Bank under the terms of international law.

Source: Barro Lee dataset: www.barrolee.com.

6. As OECD and EU countries have made education compulsory, usually between the ages of 5 to 7 and 14 to 16, secondary education attainment has become the norm for men and women. In the OECD among younger adults (that is the population aged 25 to 34), 83\% of women and 80\% of men had at least an upper secondary education degree in 2010. The gender gap was the same in EU-21 countries: $85 \%$ for women and $83 \%$ for men. Only in few countries men were more likely to have attained at least upper secondary education: Austria, Czech Republic, Germany, Mexico, Switzerland and Turkey (OECD, 2012a). Reflecting the relatively recent improvement in women's educational attainment relative to men's, in 2010 across the OECD $66 \%$ of men (68\% in the EU), but $58 \%$ of women ( $60 \%$ in the EU) in the 55 to 64 age group had attained at least upper secondary. Only in Canada, Estonia, Finland, Ireland, Sweden and the United States did women already have an advantage in the 55-64 group. 
Figure 1. Proportion of men and women that attained at least upper secondary education, by age group (2010)
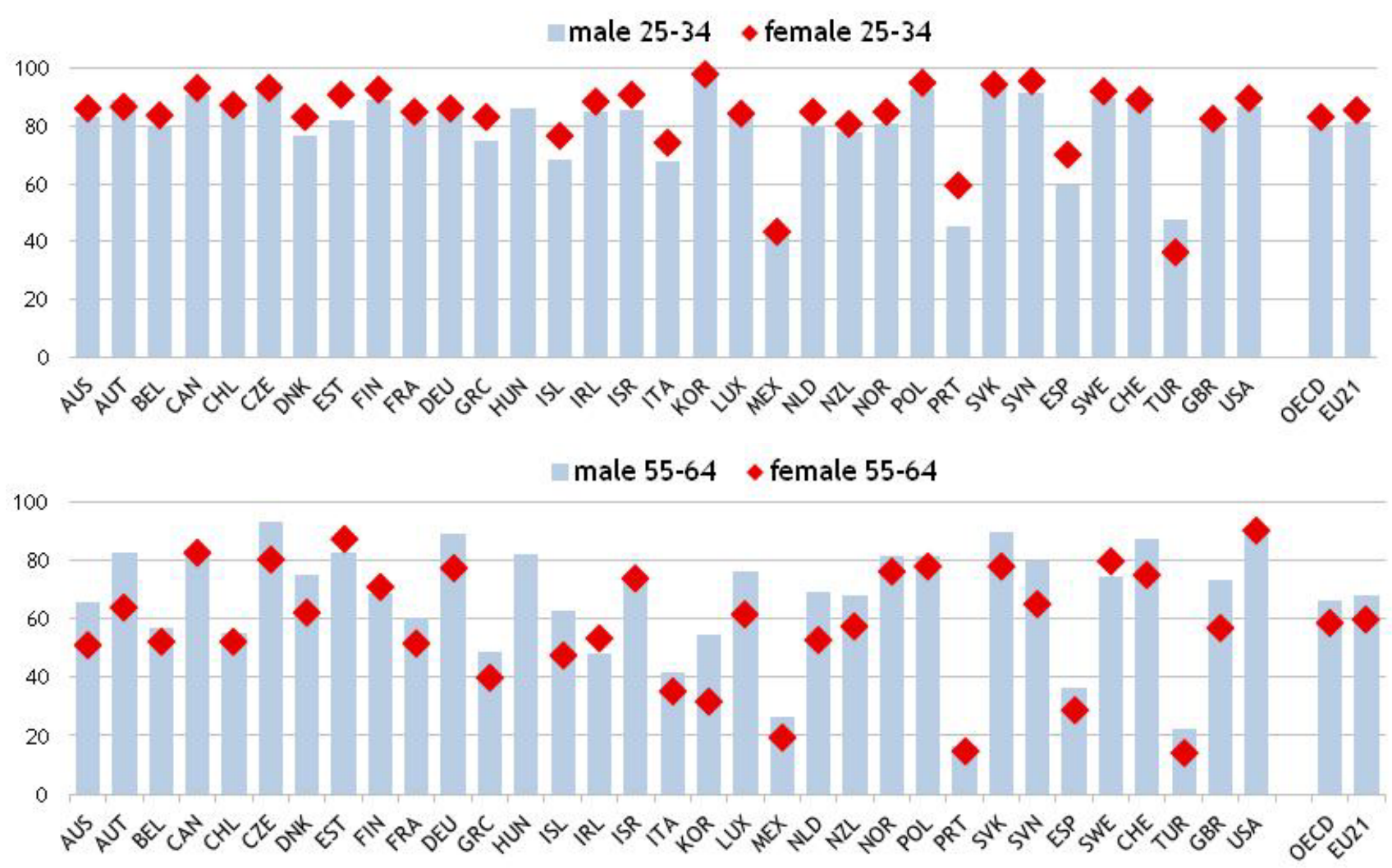

Note: gender gap is proportion among women- proportion among men.

Source: OECD Education at a Glance 2012.

7. Gender gaps are larger at the highest levels of educational attainment, as young women are more likely than young men to transition to and complete tertiary education. In $2010,42 \%$ of women and $33 \%$ of men aged 25-34 had a tertiary degree in the OECD, which include theory-based programmes (tertiary-type A), shorter and largely vocational programmes (tertiary-type B) and advanced research programmes. In the EU21, in 2010, $40 \%$ of women and $29 \%$ of men aged 25-34 had a tertiary degree; only in Switzerland and Turkey were men in this age group more likely than women to have a tertiary degree. As already observed in secondary education, for the generation aged 55-64, men were more likely than women to have a tertiary degree in 2010 (Figure 2). 
Figure 2. Proportion of men and women that attained tertiary education, by age group (2010)

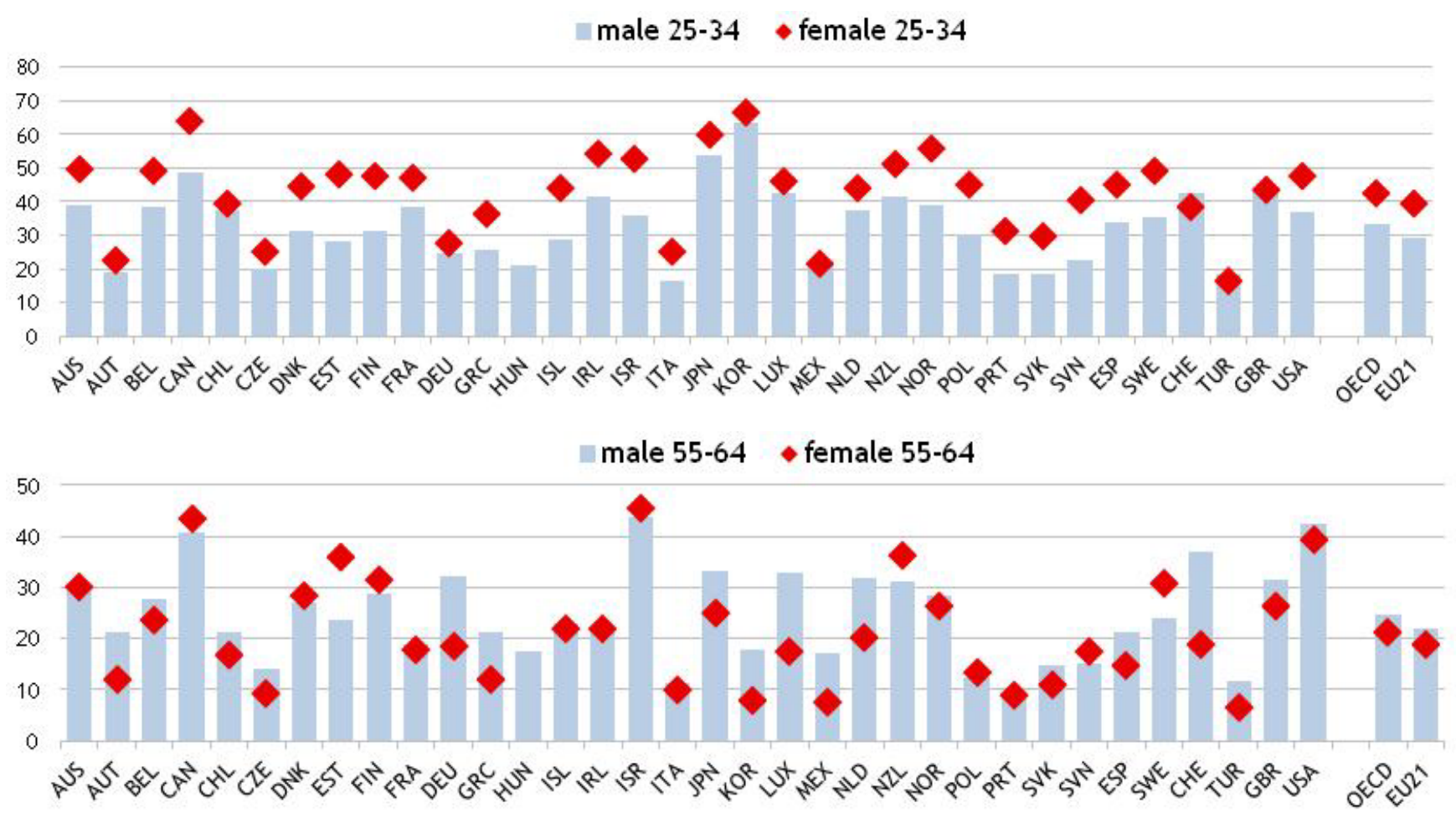

Source: OECD Education at a Glance 2012.

8. Reflecting the increasing demand for a highly skilled labour force, entry rates in type-A tertiary education has been increasing steadily over the past decades whereas entry in tertiary-type B programmes has remained stable (Figure 3). On average in the OECD, $69 \%$ of young women entered tertiary-type A education (i.e. largely theory-based) programmes in 2010, marking an increase of 9 percentage points since 2005 , and a 25 percentage point increase since 1995. Boys have followed a similar trend, reaching an entry rate of $55 \%$ in 2010 in the OECD. On average, trends and levels are very similar in the EU21 countries. Entry rates in tertiary-type $\mathrm{B}$ education programmes (i.e. shorter programmes generally focused on developing practical, technical or occupational skills) have instead remained more or less stable between 2005 and 2010, with an OECD average in 2010 of 16\% for young men and 19\% for young women. 
Figure 3. Trends in entry rates at tertiary level, by gender (2005-2010)

$\rightarrow$ Men Tertiary Type 5A $\rightarrow$ Women Tertiary Type 5a $\quad-$ Men Tertiary Type 5B $\rightarrow$ Women Tertiary Type 5B

OECD average

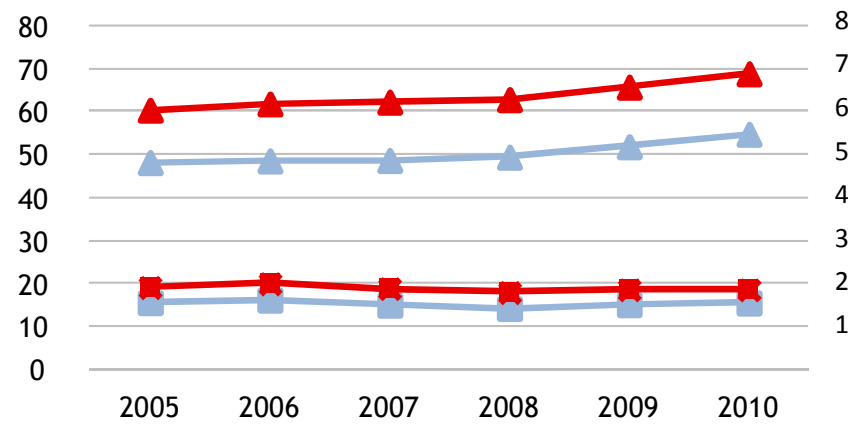

EU21 average

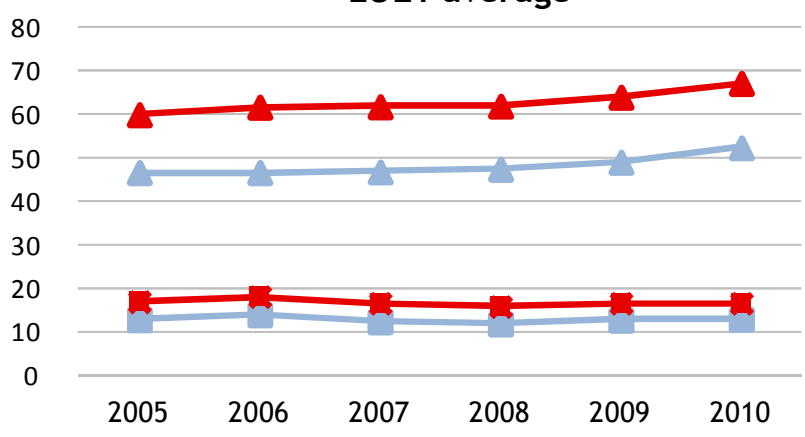

Source: OECD Education at a Glance 2012.

9. In 2010, the gender gap in entry rates in tertiary-type A education was greater than 25 percentage points, to the advantage of women, in five out of the 31 OECD countries for which data is available: Iceland, New Zealand, Norway and Slovenia. Japan was the only OECD country where the incidence of entry in tertiary-type A programmes was higher among men than among women, with an 11 percentage point difference (Figure 4).

Figure 4. Entry rates in tertiary type-A education, by gender (2010)

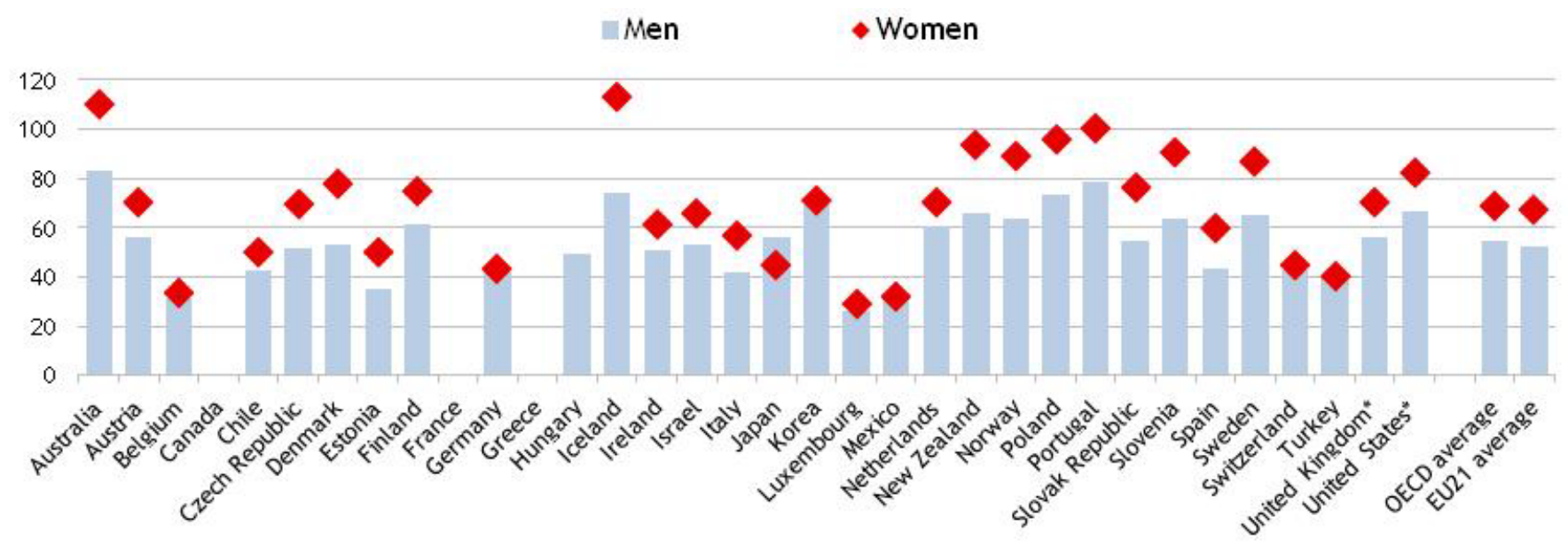

Source: OECD Education at a Glance 2012.

10. A comparison of the incidence of women among entrants and among graduates in tertiary education suggests that women might also be more likely than men to successfully complete tertiary education in most OECD countries, even though comparing entry and graduation data for the same year only provides a very rough proxy for completion (Figure 5). 
Figure 5. Proportion of women among entrants and graduates in tertiary education (2010)

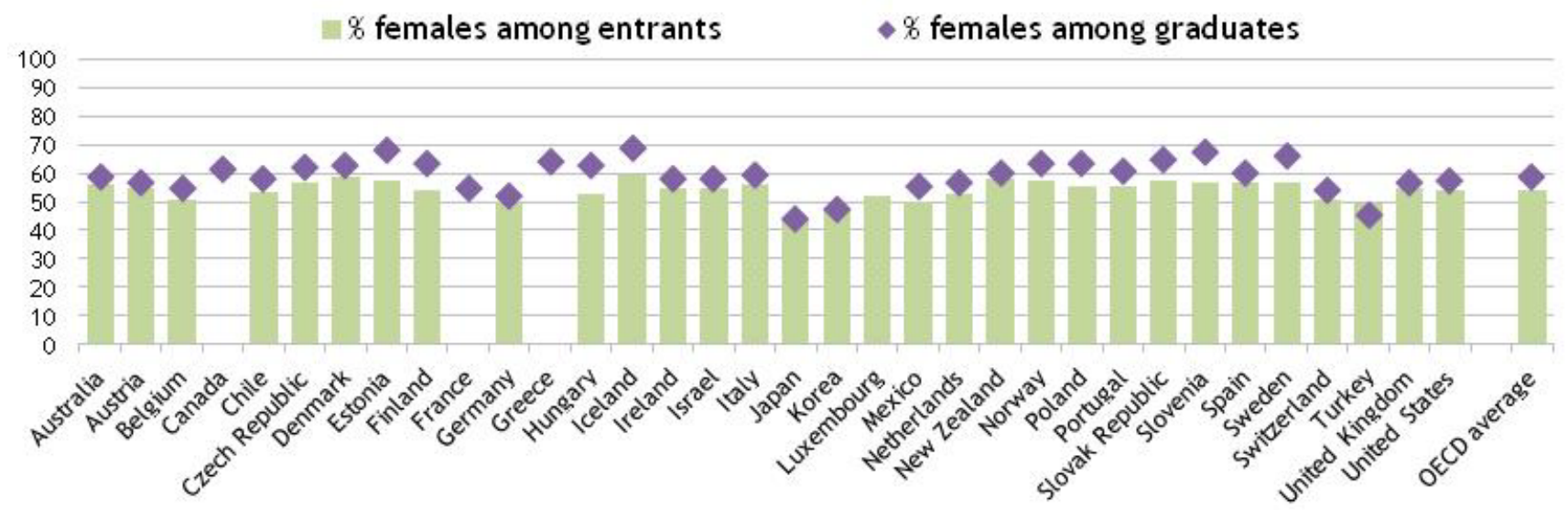

Source: OECD Education at Database 2012, OECD Education at a Glance 2012.

11. Participation of women in advanced research programmes has also been increasing over time. By 2010 , entry rates among women were at par with those of men in the majority of OECD countries for which data is available, and the proportion of advanced research degrees awarded to women in 2010 varied between $40-50 \%$ in the majority of OECD countries (Figure 6).

Figure 6. Percentage of qualifications awarded to women at different tertiary levels (2010)

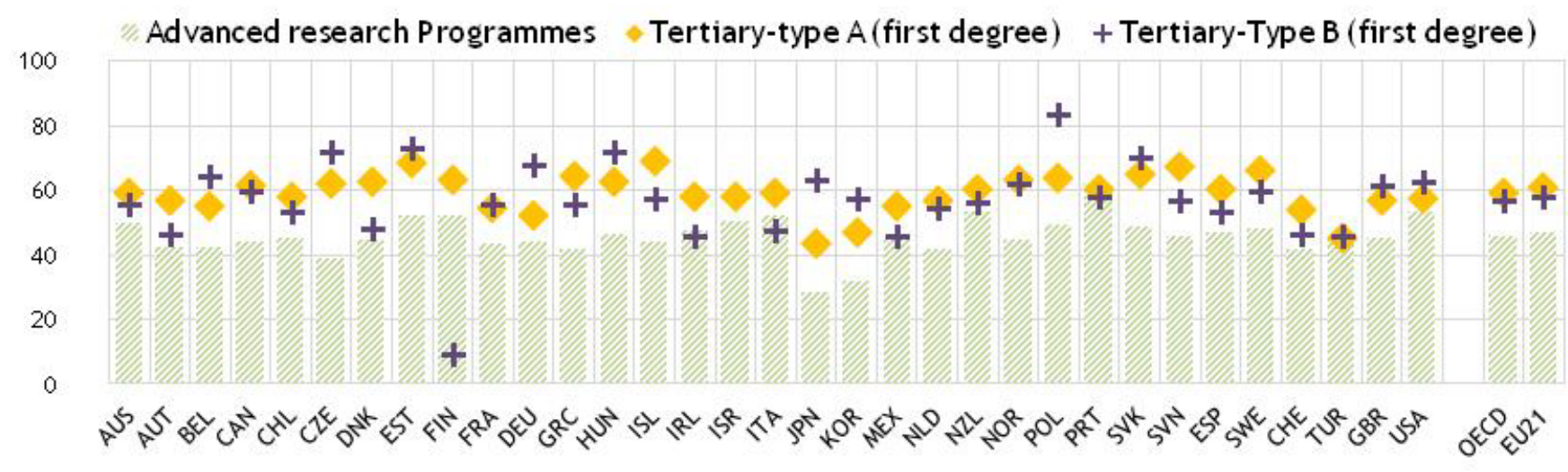

Source: OECD Education at a Glance 2012.

\section{Drivers of improved girls' education outcomes and boys' underperformance}

12. In the 1990s, participation in tertiary education among women started to increase at a faster rate than among men in many OECD countries. Figure 7 shows the trends in the ratio of female to male enrolment rates for a number of OECD countries. In the 1970s, female enrolment rates were already increasing compared to male rates - at moderate pace in some countries - but much faster in others, like the United States. In the following two decades female rates began to soar in many countries, and by 2010 enrolment in tertiary education was higher for women than for men in all OECD countries except Japan, South Korea, Switzerland and Turkey. 
Figure 7. Trends in female to male participation in tertiary education, 1970 - 2010

Ratio of number of female students enrolled at tertiary education to the number of male students
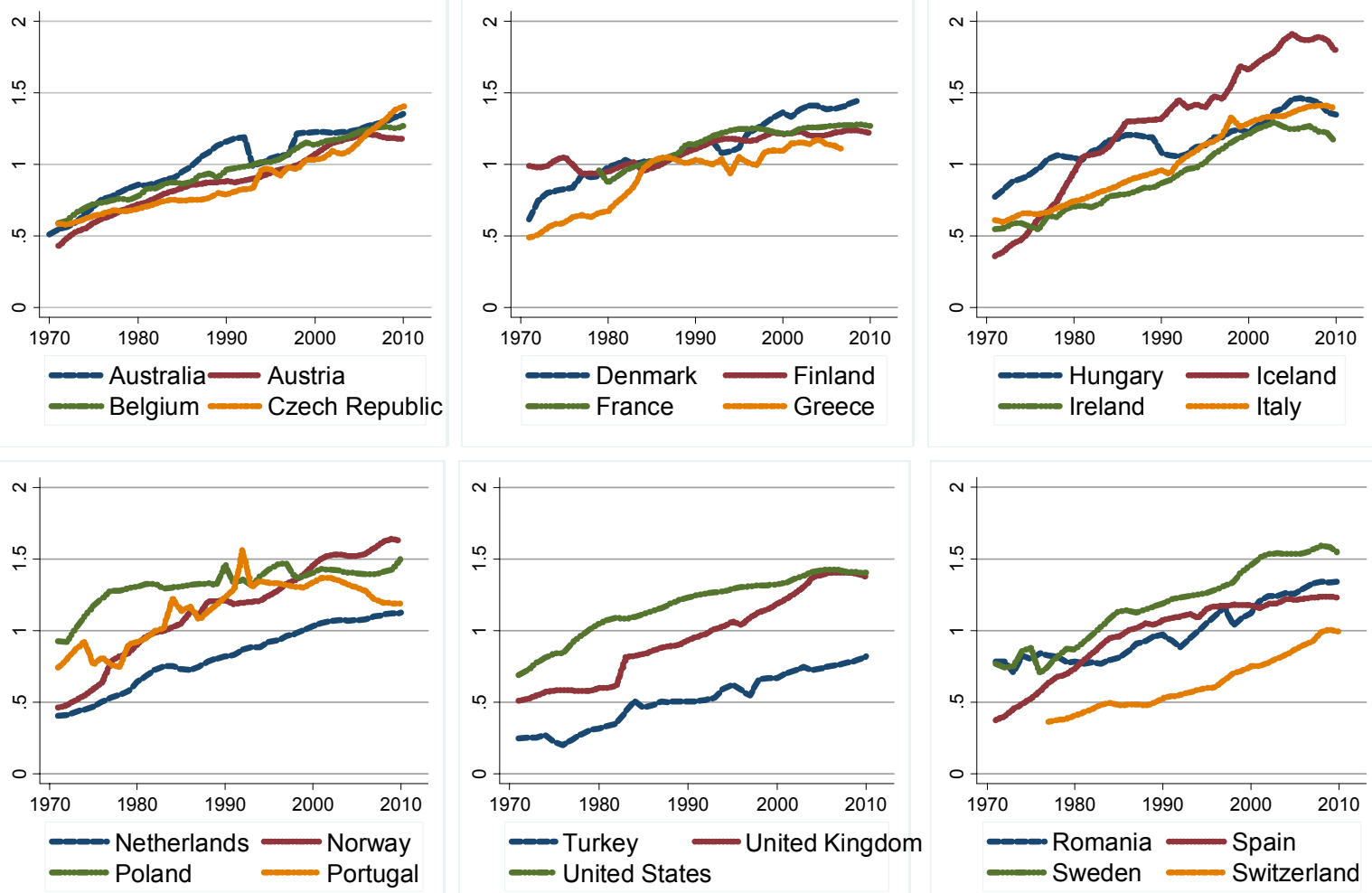

Source: UNESCO Statistical Database, 2013.

13. In the economic literature, a number of factors have been associated with women's increased participation in tertiary education. Goldin (2006) and Goldin, Katz and Kuziemko (2006) highlight the role of changing expectations about future labour force participation among women. Increased participation in the labour force among older generations is expected to have encouraged younger women to pursue tertiary education in order to improve employability (Figure 8).

Figure 8. Women's participation in the labour force and participation in tertiary education, OECD countries $1980-2010$

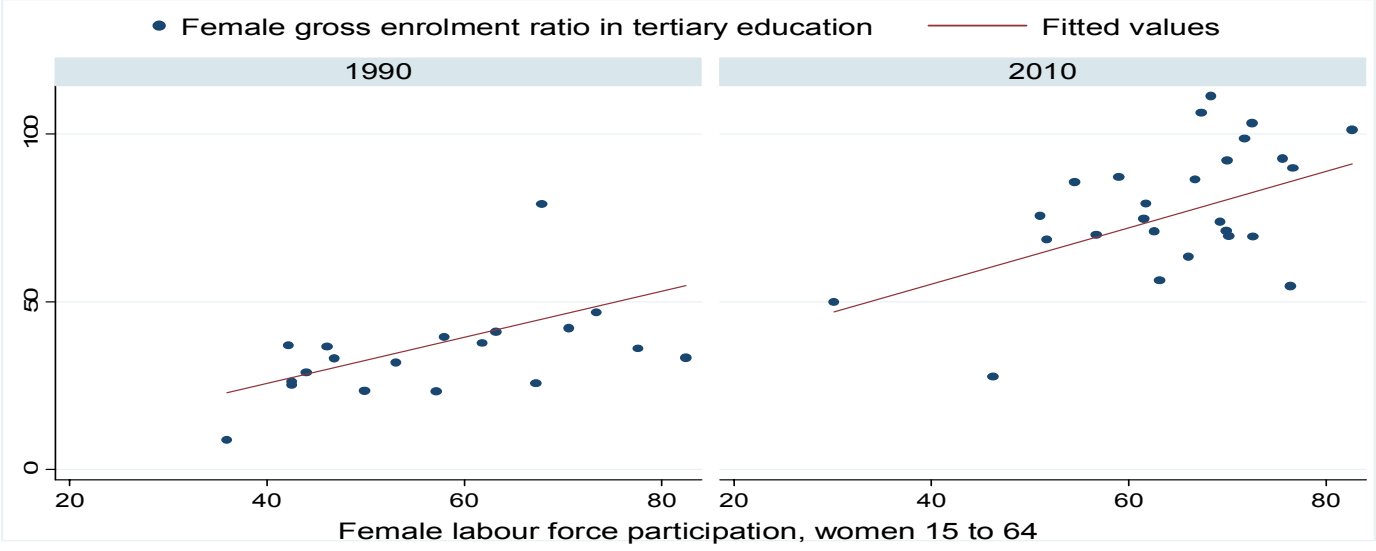

Source: UNESCO Statistical Database 2013; OECD employment database 2013. 
14. Higher educational attainment contributed to improving other labour market outcomes, such as earnings and career progression. Tertiary education yields an earnings premium in OECD countries; in 2010 workers who had a tertiary degree earned on average $55 \%$ more than workers with an upper secondary education in the OECD (Figure 9). Earnings premiums were higher for men $(60 \%)$ than for women $(57 \%)$, if the entire working-age population is considered. However, earnings premiums become larger for women (49\%) than for men (40\%) in the 25-34 age group which might help explain why young men are less likely to graduate from university.

Figure 9. Employment earnings premium, 2010 or latest available year

\section{Earnings of the population with tertiary education relative to population with upper secondary education (=100), by gender and age groups}

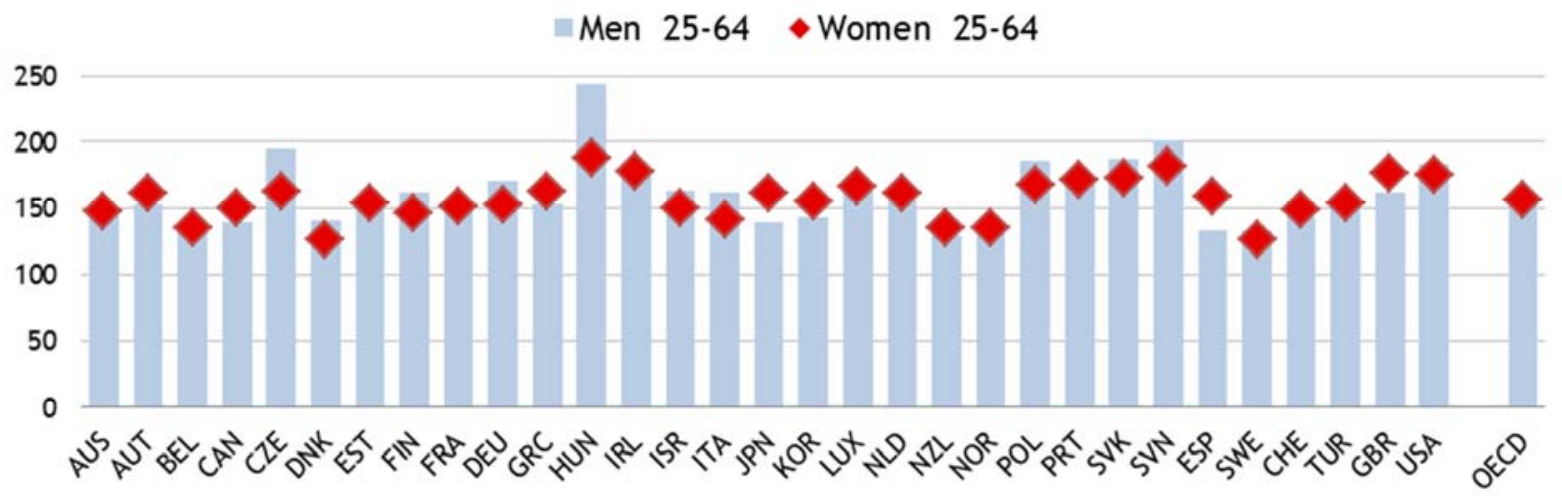

Source: OECD Education at a Glance 2012.

15. Having a tertiary degree does not contribute to reducing gender gaps in earnings in every OECD country. (Figure 10). By looking at countries such as Greece, Spain and the United Kingdom, gender gaps in earnings were actually smaller among unskilled workers (i.e. those who did not complete upper secondary education) than those with a tertiary degree.

Figure 10. Differences in earnings between women and men, 2009

Average annual earnings of women as a percentage of men's earnings, by level of educational attainment of 25-64 year-olds

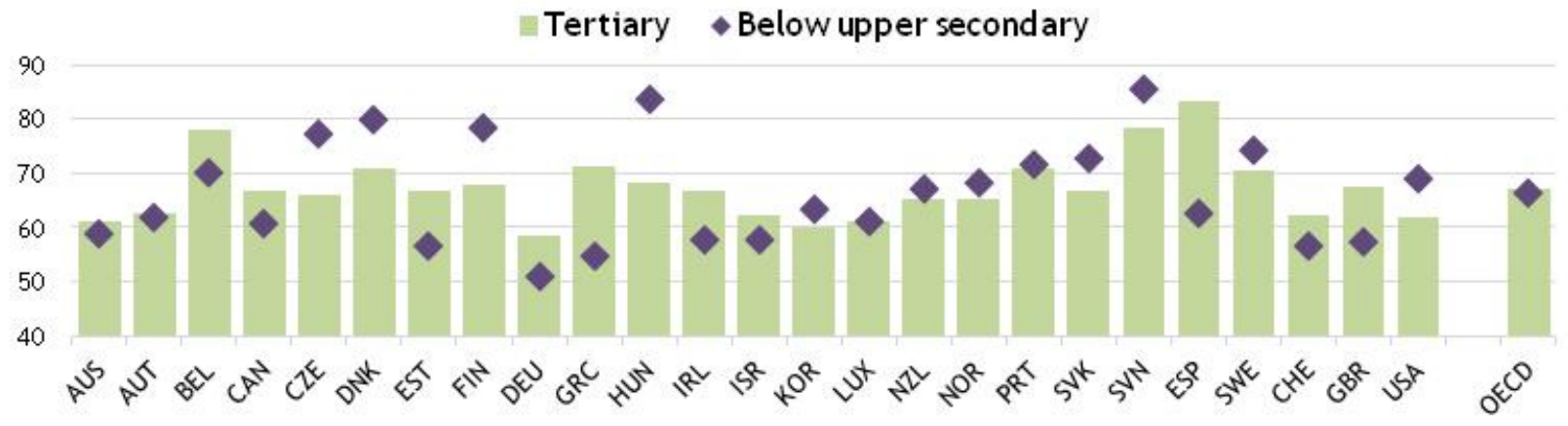

Source: OECD EAG 2012.

16. Naturally, the positive correlation between labour force participation and educational attainment does not indicate causality, and it is in fact likely that both trends were caused by other factors such as: the role of technological changes that reduced the time needed to carry out unpaid work in the household (Chiappori et al., 2009); contraceptive innovations (Goldin and Katz, 2002); increases in the median age of first marriage and average age at first birth (Figure 11); and increases in divorce rates and decreases in 
rates of marriage, which pushed women to invest in their own human capital to ensure economic autosufficiency (DiPrete and Buchmann, 2006; Goldin, Katz and Kuziemko, 2006). While many other additional and social factors are likely to affect - from an early age - the probability of attending tertiary education, the trends in labour markets described above can have significant effects on investments in education on the margin (DiPrete and Buchmann, 2006).

Figure 11. Age at first birth and women's participation in tertiary education, OECD countries, 2009

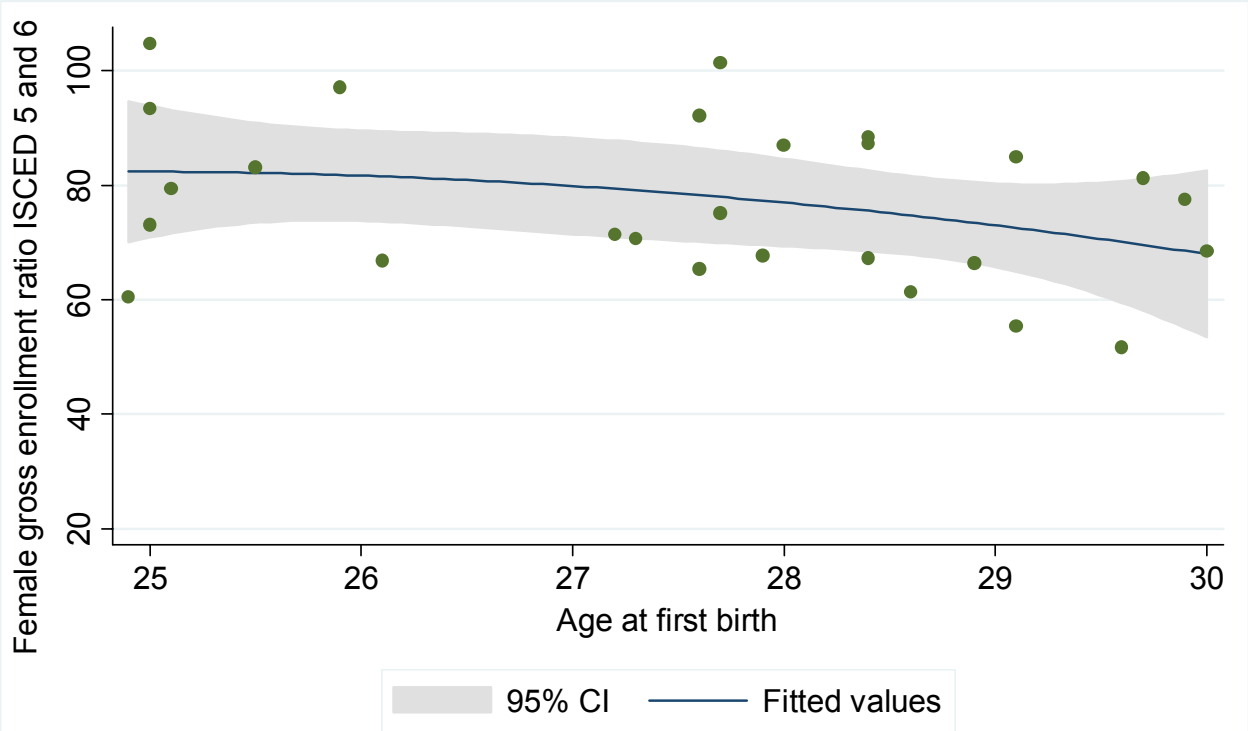

Source: UNESCO and OECD Family Database.

17. Having an upper secondary education degree is critical for entering and staying in the labour market. As shown in Figure 12, men have an even higher penalty than women, in terms of employment rate, for failing to complete at least an upper secondary education degree. At the same time, the fact that lower secondary education employment rates are higher in level for men than for women might give lowskilled boys more incentives to drop out compared to low-skilled girls.

Figure 12. Employment rates by educational attainment and gender, 25-64 year-olds 2010

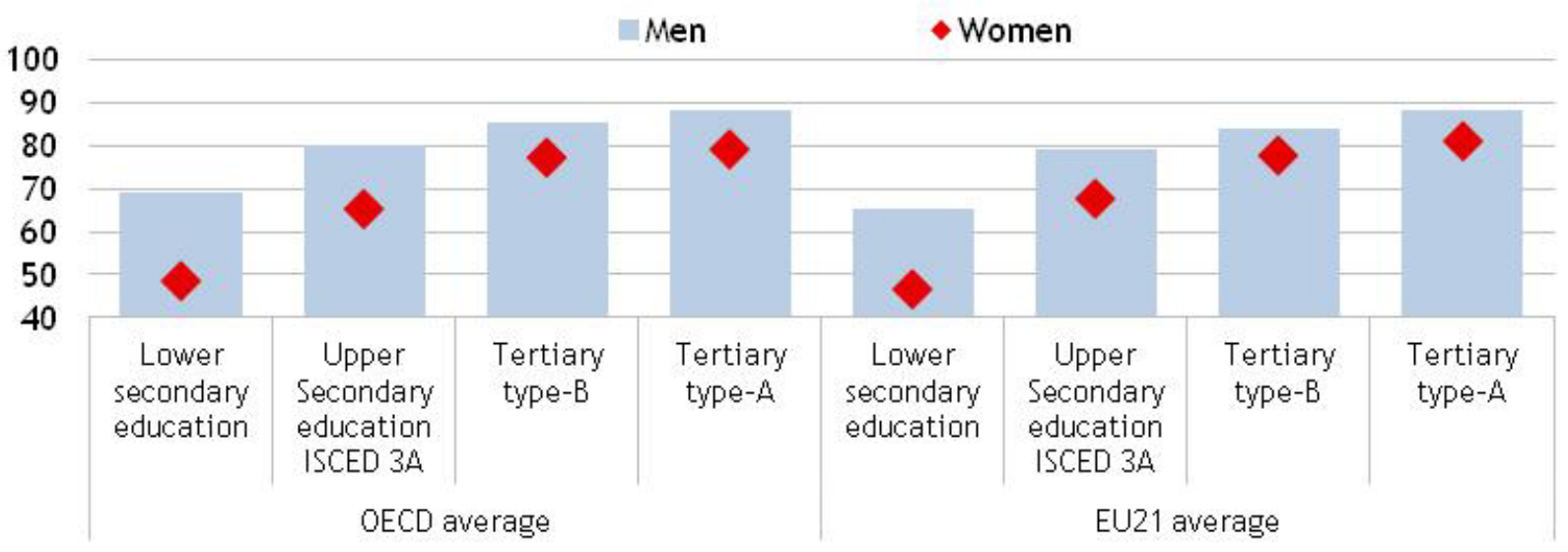

Source: OECD EAG 2012. 
18. Overall gender gaps in educational attainment are mainly the consequence of higher participation and more successful completion of tertiary degrees among women. However, boys start falling behind before entry into post-secondary education. In the OECD and EU countries, education is nowadays compulsory (usually) between the ages of 5 to 7 and 14 to 16; for this age group access and participation in education is therefore universal. However, upon completion of lower secondary education, most OECD countries allow students to leave the education system. As a result, gender differences in participation rates begin to appear at the start of upper secondary education.

19. In 11 out of the 34 OECD countries, less than $80 \%$ of boys and girls aged 15 to 19 are enrolled in school (Figure 13). In every OECD and EU21 country, the enrolment rate among 15- to 19-year-olds is higher for girls $(84 \%)$ than for boys $(82 \%)$. The gender gap is even larger in EU21 countries; enrolment rates are $88 \%$ for girls and $85 \%$ for boys in this age group. Among the OECD European countries, the gender gaps are largest in Greece, Portugal, Spain and the United Kingdom. Switzerland and Turkey are the only OECD countries where boys aged 15 to 19 are more likely to be enrolled in formal education than girls of the same age.

Figure 13. Enrolment rate in education for population aged 15 to 19 , by gender (2010)

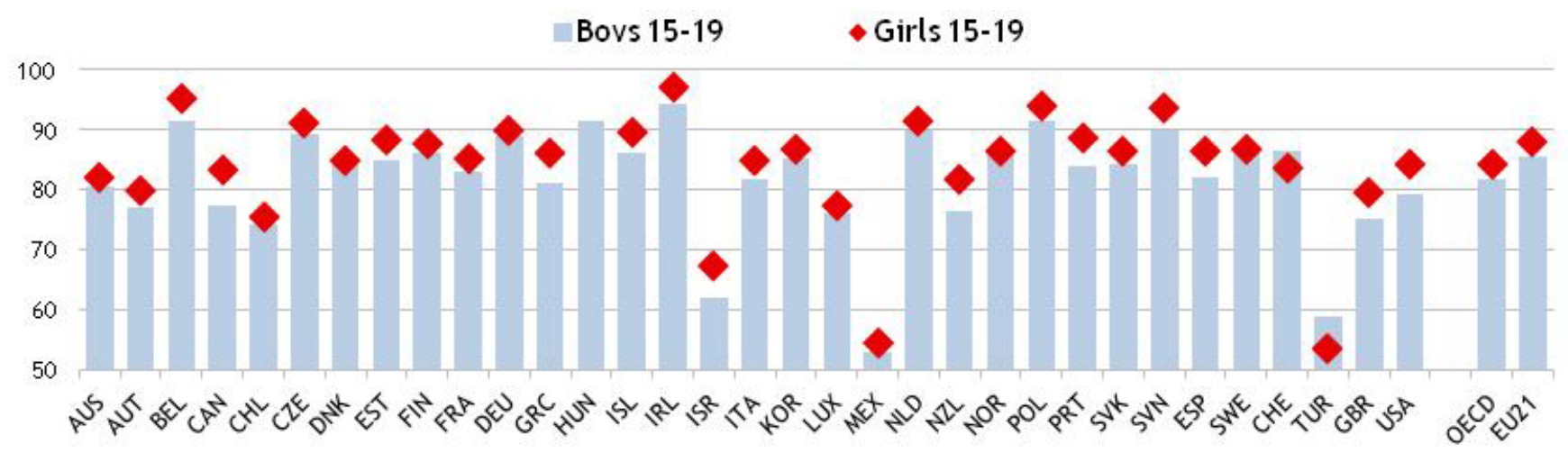

Note: Full-time and part-time students in public and private institutions.

Source: OECD Education at a Glance 2012.

20. Boys are not only less likely than girls to enter upper secondary education; they are also less likely to complete these programs once they started. While data are available only for a subset of countries, they show a clear gender gap in successful completion rates. On average in 2010 , across the countries for which there is data, $66 \%$ of boys completed their upper secondary education within the stipulated time, compared to $74 \%$ of girls. The gender gap in completion rates was smaller than 5 percentage points in a few countries (Finland, Japan, Korea, the Slovak Republic and Sweden), while it exceeded 15 percentage points in Iceland and Norway (Figure 14). 
Figure 14. Successful completion of upper secondary programmes, by gender (2010)

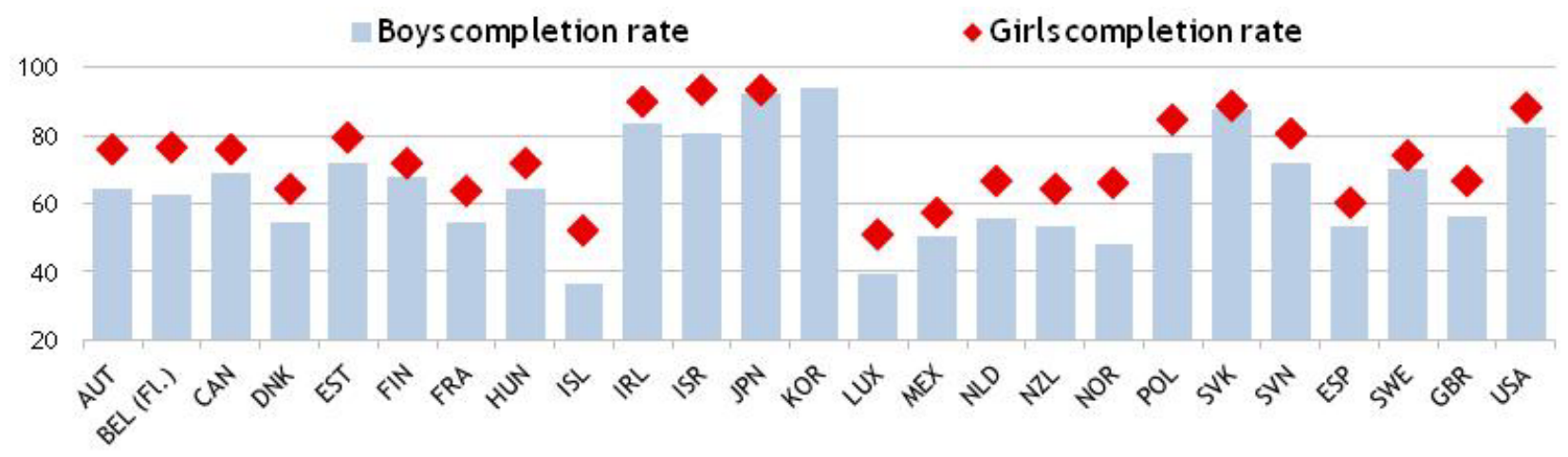

Source: OECD; Education at a Glance 2012.

21. In many OECD countries boys also tend to have poorer school performance than girls, in terms of grades, repetition rates and attendance (OECD, 2011). On average girls receive better marks from their teachers than boys. In the majority of countries for which data are available ${ }^{1}$, gender gaps in marks remain significant even after controlling for reading performance and learning habits (OECD, 2012e). Marks have an important role in shaping students' education expectations by providing them an important source of information on their success and potential in school. In fact, marks are found to be significantly related to education outcomes, such as university completion. In many countries and economies, gender differences in marks explain a significant part of gender differences in expectations to complete a university degree, net of performance and secondary education programme (OECD, 2012e). It will therefore be important to better understand whether systematic differences in marks obtained by boys and girls with similar skills are systematically related to socio-economic background and/or stereotypes.

22. Grade repetition is also more common among boys than girls. PISA 2009 provides information about self-reported past grade repetition among 15-year-old students. On average, in the OECD, 8\% of 15year-old boys and 5\% of girls report having had to repeat (once or more than once) a grade in lower secondary education. Gender differences vary by countries and are of course larger (and statistically significant from zero) in countries where having underperforming students repeat grades is a more common practice, such as in France, Luxembourg, Portugal and Spain (Figure 15).

23. The gender gaps in the proportion of students who report having repeated a grade remain significant even after controlling for the student's socio-economic background and immigrant status, factors which can have significant effects on the likelihood of repeating a grade for both boys and girls. Fifteen-year-old students who are from lower socio-economic backgrounds or vulnerable social groups are twice as likely to repeat one or more grades, and they are at a higher risk of not completing secondary education (OECD 2011). Gender compounds these differences; Bertrand and Pan (2011) find that this might be driven by a stronger relationship between behavioural outcomes and parental inputs for boys than for girls. Boys growing up in families from lower socio-economic backgrounds would therefore be doubly disadvantaged if they have fewer opportunities to spend time in childcare-related activities with their parents. Ethnic origin and language are also expected to interact with gender differences in education performance (European Commission, 2010).

\footnotetext{
${ }^{1}$ In 2009, in 21 of the PISA participating countries students provided information about their expectations in terms of educational attainment; in 17 of these countries (Austria, Belgium, Hungary, Iceland, Ireland, Italy, Mexico, New Zealand, Poland, Portugal, the Slovak Republic and Croatia, Latvia, Macao-China, Serbia, Singapore and Trinidad and Tobago), students also reported information on their marks.
} 
Figure 15. Proportion of student who report having repeated a grade in secondary education (2009)

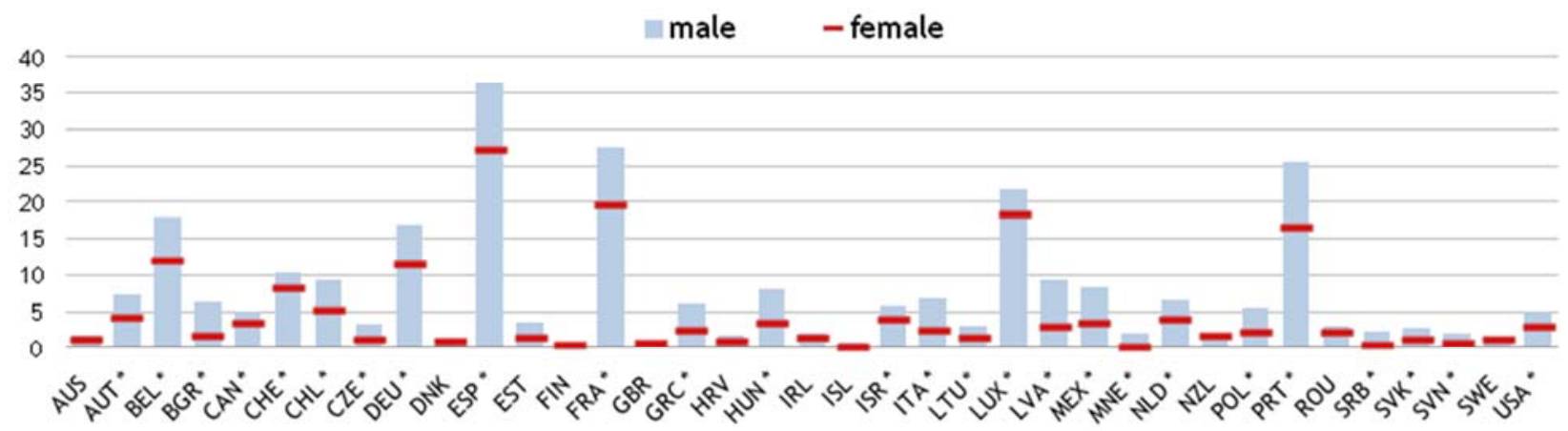

Note: Proportion of students who report having repeated a grade once or more in ISCED 2 out of the students who report whether or not they repeated the grade. * indicates that gender difference is statistically significant at the $95 \%$ confidence level.

Source: PISA 2009 dataset.

24. Expectations about academic achievement prior to entering higher education are also likely to influence actual outcomes. PISA data (OECD, 2012e) show that expectations about education attainment are higher among girls than boys (Figure 16). In most countries for which data is available, the share of students expecting to complete a university degree increased between 2003 and 2009 (Figure 16); in about half of the countries the increase was somewhat greater among girls. While socio-economic status is the largest predictor of educational expectations (McDaniel, 2010), the gender gap in the proportion of students that expect to complete a tertiary degree is significant even after controlling for socio-economic and immigrant background and for performance in mathematics and reading.

Figure 16. Proportion of students expecting to complete a university degree, by gender at age 15

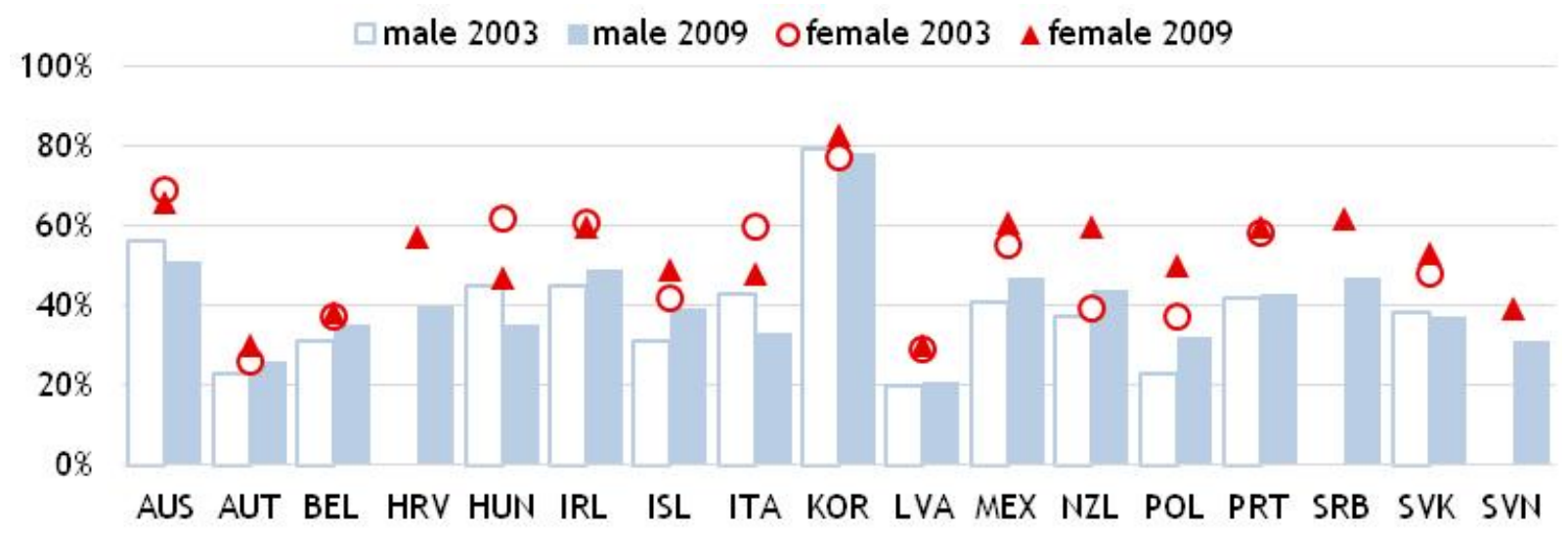

Source: PISA 2003, PISA 2009.

\section{Gender differences in subject choice in tertiary education}

25. The evidence presented so far shows that women have, overall, higher educational attainment than men in most OECD and EU countries. Nevertheless, clear gender stratification in the type of educational curricula and field of study taken by young women and men persist. Young women are much less likely than young men to choose certain scientific fields, while young men are unlikely to graduate from fields such as health, welfare and the humanities. 
26. In 2010, women accounted for $74 \%$ of the graduates in education, health and welfare, and for $77 \%$ in humanities in OECD countries. On the other hand, they made up $27 \%$ of the graduates in engineering and 20\% in computer sciences (Figure 17). Only in Estonia, Finland, Greece and Portugal were science-related fields of study more attractive to women. In no OECD country was there gender parity in the share of degrees awarded in these fields. The same holds true for degrees in education; in each of the OECD countries except for Japan and Turkey, men accounted for less $40 \%$ of the graduates in this field of study, and for less than $10 \%$ in Italy and Estonia. Even within subject areas there is evidence of segregation. For example, in science women still prefer fields such as biology, medicine and agriculture whereas men continue to dominate mathematical and physical sciences, in particular, engineering (Xie and Shauman, 2003).

Figure 17. Proportion of degrees awarded to women, selected fields of study (2010)

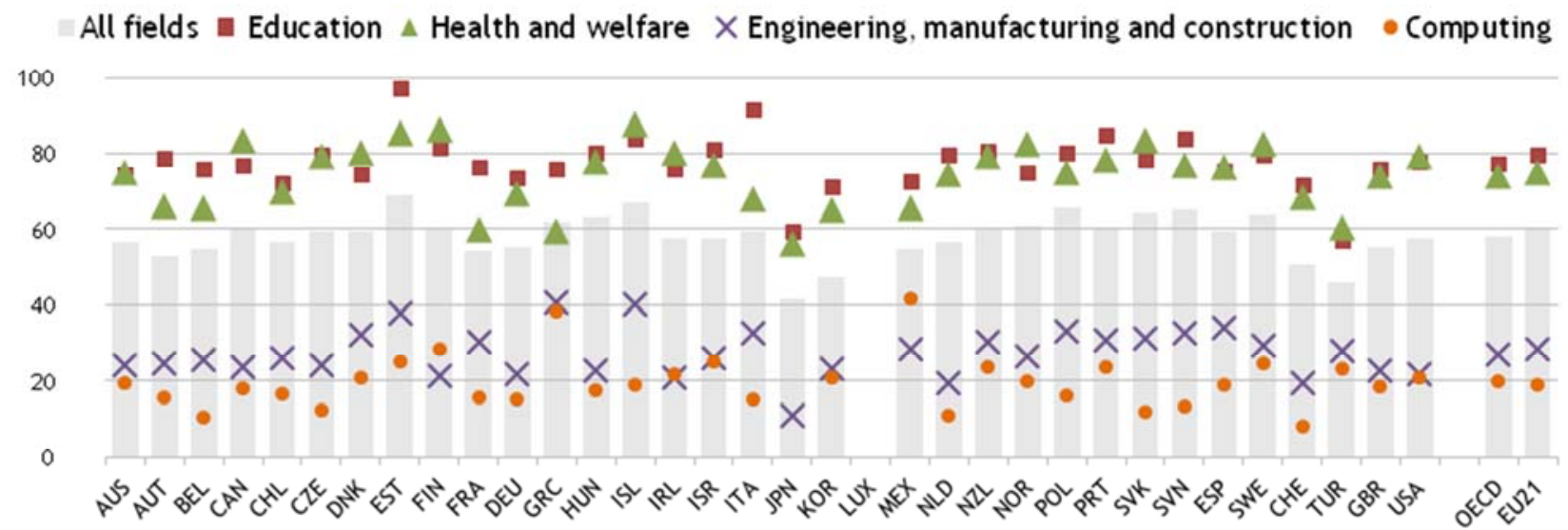

Note: Tertiary type-A and advanced research programmes.

Source: OECD Education at a Glance 2012.

27. Over the past decade, this polarization has decreased only slightly and only in some fields of study (Figure 18). The Czech Republic, Germany, the Slovak Republic and Switzerland are the only four countries where the proportion of women in science grew by at least 10 percentage points between 2000 and 2010. The share of women in computer sciences has actually decreased in the past 10 years in most OECD countries. Only in Austria, the Czech Republic, Germany and Norway was the share of women among graduates in computing sciences higher in 2010 than in 2000. Engineering schools have instead been somewhat more successful in increasing female representation. In most OECD countries the share of women among engineering graduates increased between 2000 and 2010, with an average increase of 5 percentage points in both the OECD and the EU. 
Figure 18. Change in the proportion of tertiary degrees awarded to women by field, 2010-2000

Percentage points differences

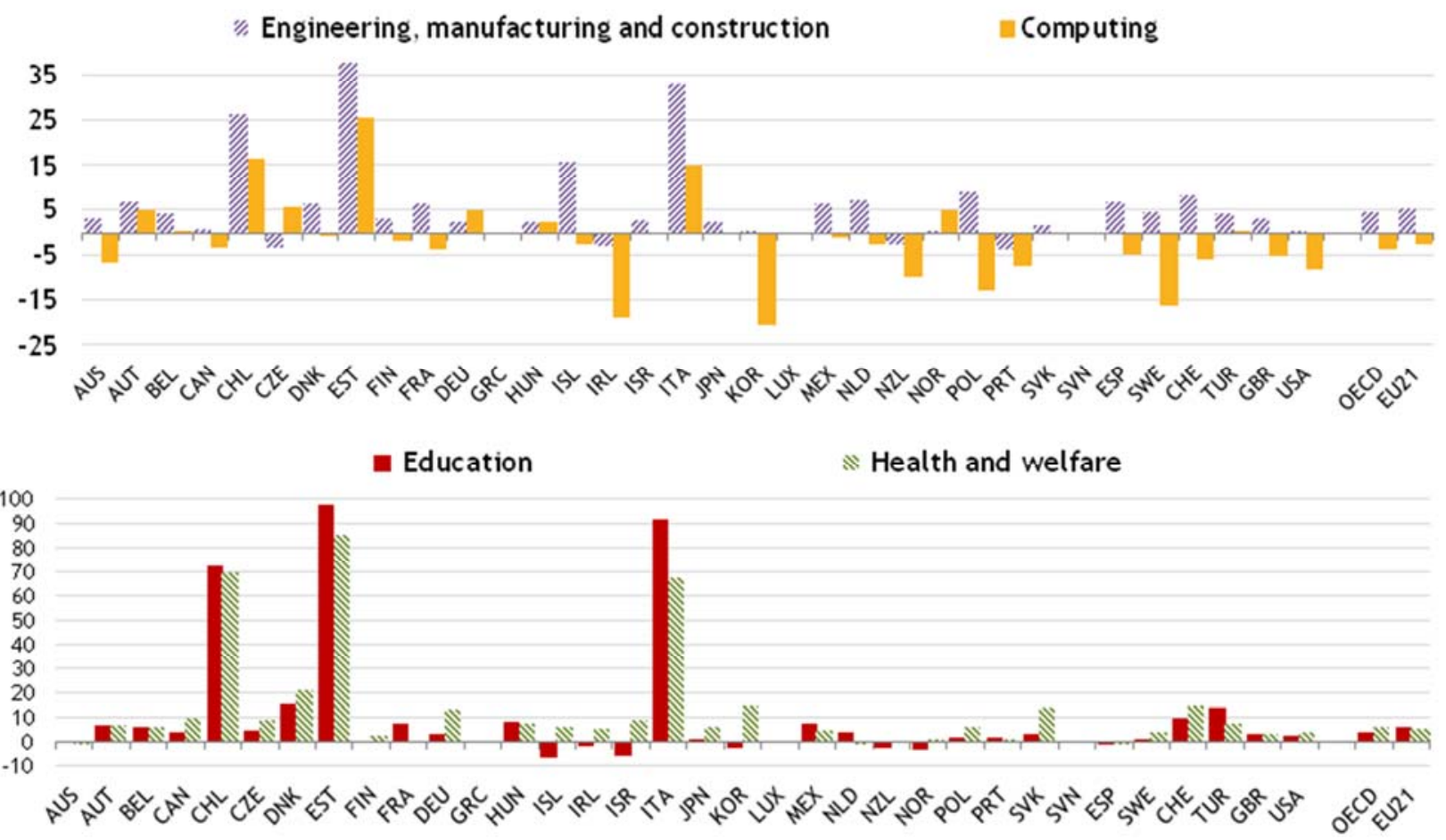

Note: Tertiary-type A and advanced research programmes.

Source: OECD 2012 EAG.

28. This partial de-segregation of fields of study was driven more by women entering maledominated fields of study than by males entering female-dominated fields of study (England, 2010). Gender disaggregated data on the number of graduates by field of study (Figure 19) reveal that between 2000 and 2010 the number of male graduates in computer sciences increased significantly in the OECD, in response to employment opportunities in the field. The number of female graduates in the field has instead remained, by and large, unchanged over the same period of time. Women have lagged behind in engineering as well (Figure 19), even though the trends in the number of female graduates have been slightly more positive than in computer sciences. Strong positive trends have been observed in a few countries: Denmark, Iceland, Poland, the Slovak Republic as well as Belgium and Spain. 
Figure 19. Trends in number of graduates in tertiary education by field of education, OECD average 1998-2010
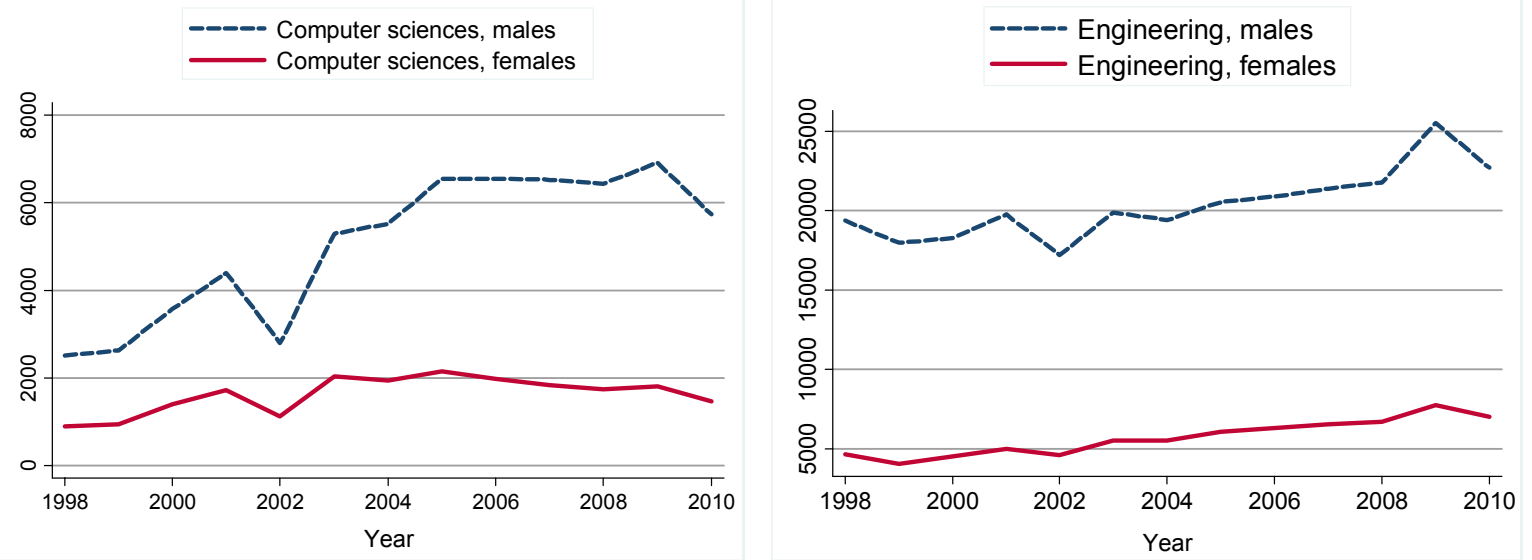

Note: Tertiary-type A and advanced research programmes. Engineering is ISIC500.

Source: OECD Education database.

29. Polarization has also increased in health and welfare; on average the proportion of women among health and welfare graduates has increased by 6 percentage points in the OECD and in the EU (Figure 18). With the exception of Australia and the Netherlands, the proportion of women among graduates has further increased between 2000 and 2010 in all other OECD countries for which there is data. While over the past decade gender polarization also increased in education degrees in the OECD and the EU (on average by 4 and 6 percentage points respectively), the share of men in the field has increased in countries such as Iceland, Ireland, Korea, New Zealand, Norway and Spain.

\section{Drivers of gender differences in subject preferences}

30. Many factors can influence students' subject choice in higher education, including performance in secondary education, preferences and perception of one's own ability, socio-economic and family background, career aspirations and labour market expectations.

31. Systematic gender disparities in subject choices - to the extent that they are not explained by innate differences in preferences - prevent economies from making full use of their talent pool and therefore imply a misallocation of human capital and a loss in potential innovation and economic growth. At the same time, the under-representation of women among science graduates affects their career opportunities, mainly by precluding them access to a number of occupations that often offer better earning and career potential.

\section{Gender differences in secondary education student performance}

32. The first part of this section provides a review of gender differences of student performance by subject in secondary education, as measured by the OECD PISA surveys. These data reveal that, across OECD countries (as well as many other non-OECD countries) systematic differences exist in student performance ${ }^{2}$ across subjects (reading, mathematics and sciences). In the second part of the section, we will assess whether PISA gender gaps in performance by subjects explain gender differences in the field of study chosen in tertiary education.

\footnotetext{
${ }^{2}$ PISA surveys students at age 15 when, in most OECD countries, students are near the end of compulsory education.
} 
33. Biological gender differences in non-cognitive skills, such as spatial ability, might be a factor in gender differences in student performance (Wilder and Powell, 1989). While it is very complicated to disentangle innate behaviours from learned ones, and the influence of gender stereotypes on these behaviours, the evidence presented in the rest of this section will show that attitudes and gender patterns of socialization clearly play a role in the observed differences in student performance by subject. Furthermore, gender differences in cognitive skills are small compared to the within-gender differences.

34. In each OECD and EU country, and indeed in each country and economy that participates in PISA, 15-year-old girls perform better than boys in reading (Figure 20). Across the OECD the average reading performance is 474 score points for boys and 513 for girls (i.e. a gender gap of 39 score points which is roughly equivalent to one year of schooling). In many countries differences are even greater. In Finland and Slovenia, for example, the gender gap (55 score points) is equivalent to almost 1.5 years of schooling (OECD, 2012b). Boys have significant disadvantages in reading performance in other Nordic countries as well, with the exception of Denmark. Gender gaps in reading are narrowest in the Netherlands and the United States, but at around 24 score points they are still significantly different from zero.

35. Gender gaps in reading are wider and more systematic than the gender gaps in mathematics or sciences, and have been since 2000 - the year of the first PISA assessment.

Figure 20. Gender differences in PISA reading performance, 2009

PISA score points - Reading

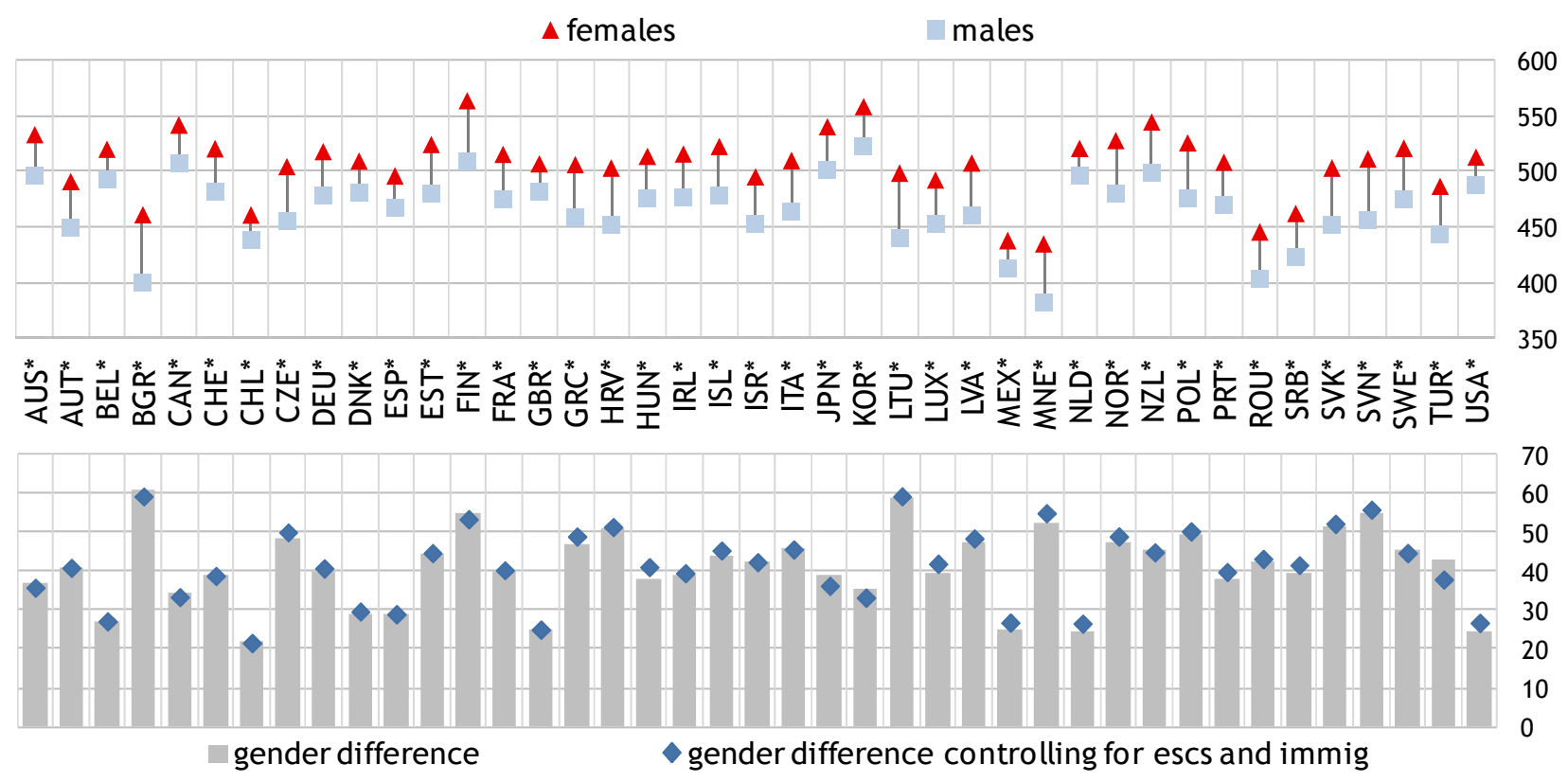

Note: the score difference is defined as girls score - boys score. Countries where gender gaps are statistically significant are identified by the symbol *.

Source: OECD PISA 2009.

36. Because both PISA 2000 and PISA 2009 focussed on reading skills, it is possible to analyse changes in gender gaps in reading performance between these two survey years. Over this period of time in most countries for which the comparison is possible, there were no significant changes in the gender gap in reading (Figure 21). However, in Israel, Korea and Romania, the gaps increased considerably (more than 20 score points). The gaps also increased in Portugal (13 score points), France (by 11 score points) and Sweden (9 score points). 
Figure 21. Change in reading performance, 2000 to 2009

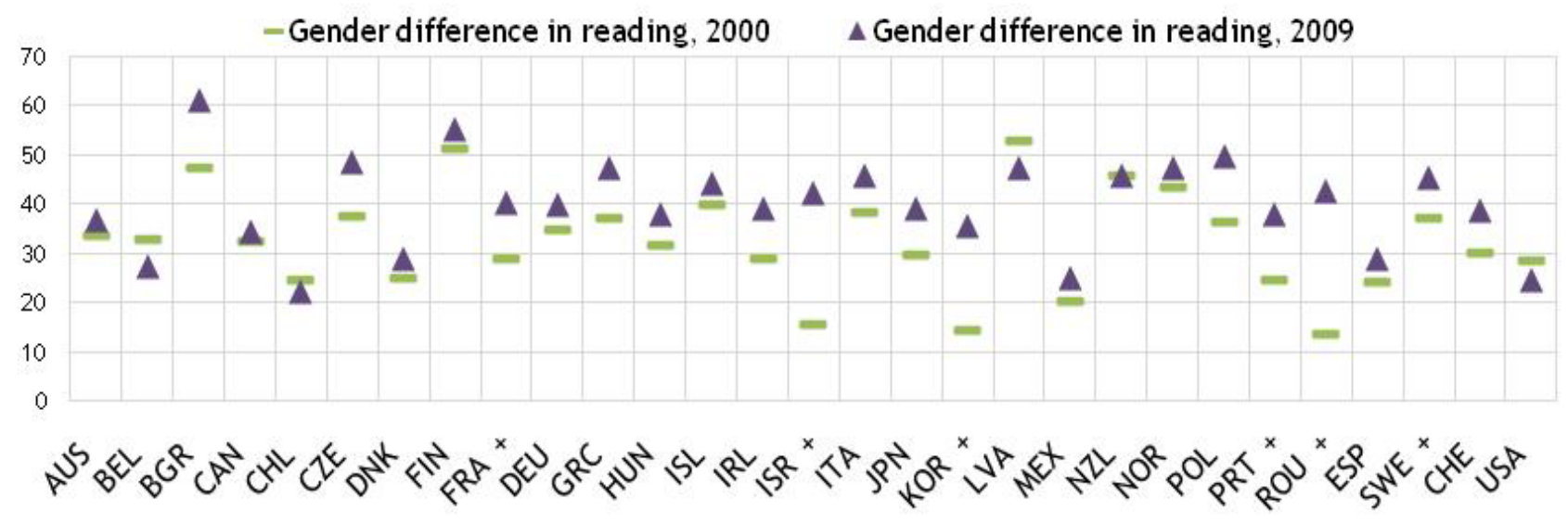

Note: symbol + indicates gender gaps are larger in 2009 than in 2000 at 95\% confidence level.

Source: OECD 2012 PISA 2009 Results: Learning Trends (Vol. V).

37. An international assessment of reading comprehension at an earlier age has been conducted within the "Progress in International Reading Literacy Study (PIRLS)", which surveys students in $4^{\text {th }}$ grade. The results of the latest wave of this survey, conducted in 2011, show that gender gaps in reading performance are already observable in $4^{\text {th }}$ grade in participating countries (Figure 22). In grade 4 (PIRLS), girls had significantly higher reading achievement than boys in all except two countries, Luxembourg and Spain, where average achievement for males and females was equal. On average across the participating countries females scored 16 score points more than males in a test where the mean score was 500 and the standard deviation 100.

Figure 22. PIRLS reading performance by gender in 4th and 8th grade

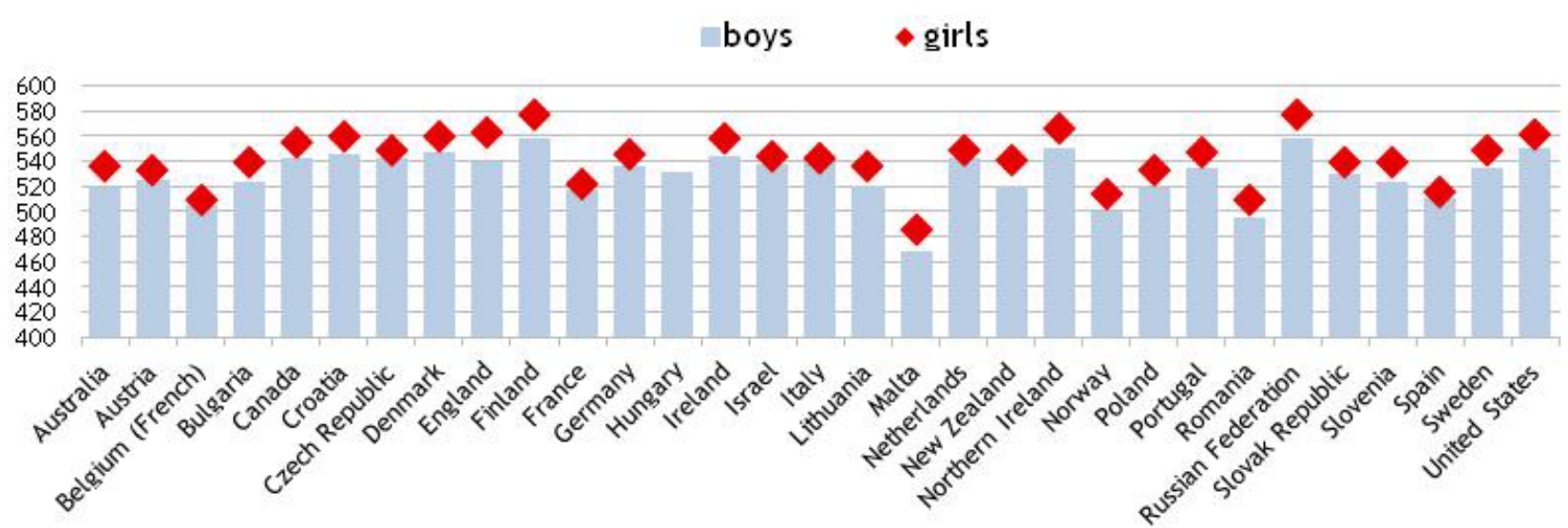

Source: International Association for the Evaluation of Educational Achievement, 2012, PIRLS 2011 international Results in Reading.

38. The gaps in reading performance measured in grade 4 by PIRLS would appear to be narrower than the gaps observed at age 15 in the PISA. Unfortunately this is only suggestive of a widening of the gender gap in reading between primary education and secondary education, because significant differences in the sampling and testing strategies of PISA and PIRLS do not allow full comparability of the results. But the fact that both in the PISA and PIRLS surveys the extent of gender gaps in reading performance (as well as performance in mathematics in PISA and TIMSS) varies considerably across countries suggests that gender gaps are not explained by inherent gender differences in academic strengths. 
39. Information collected on attitudes towards reading, mathematics and sciences in the PISA survey show that gender gaps in students' performance are related to gender differences in their attitudes towards each subject. Two broad type of attitudes towards reading are examined in PISA (OECD, 2010a): engagement in reading (i.e. whether, how much and what students read for enjoyment) and approaches to learning (to what extent students know and use effective learning strategies to understand, remember and summarise information). PISA data show that 15 -year-old female students are more likely to read for enjoyment ( $73 \%$ vs. $52 \%$ ) and read complex works of fiction and non-fiction, whereas boys are more likely to read comic books, which could partly be the result of their weaker reading skills. Between 2000 and 2009 in most OECD countries, the share of students who read for enjoyment declined both among boys and girls, but more so among boys, thus widening the gender gap. On average, girls also tend to have more effective approaches to learning, i.e. they are more effective in understanding, remembering and summarizing the material they read (OECD, 2010a). Analyses show that engagement in reading can explain $18 \%$ of the variation in reading performance of 15 -year-old students across the OECD, while approaches to learning can explain 8.2\% (OECD, 2010a). In other words, the average OECD gender gap in reading performance could be reduced by 14 points if boys approached learning as effectively as girls, and by over 20 points if they were as engaged in reading as girls. Improving engagement in reading and learning strategies among boys in the bottom quarter of the socio-economic background index would have even larger effects (Figure 23).

Figure 23. The role of engagement in reading and approaches to learning in compounding gender differences in reading performance, OECD average, 2009

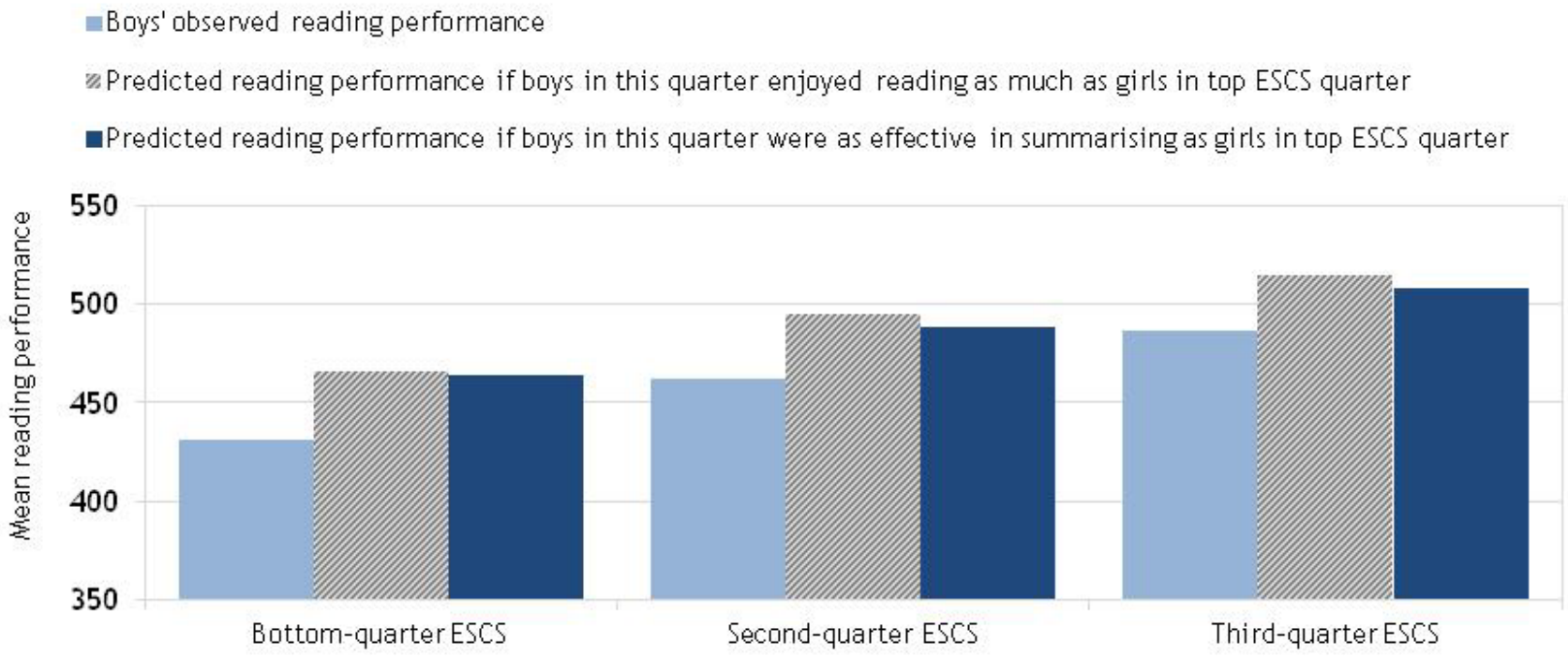

Note: Observed boys' reading performance refers to mean reading performance of students with non-missing information on the index of enjoyment of reading. The index of enjoyment captures is derived on students' agreement on a number of reading-related activities. The index of summarising is derived on students' strategies for summarising a complex text. ESCS is the PISA index of economic, social and cultural status.

Source: OECD 2012, PISA 2009 Results: Learning to Learn.

40. Various possible reasons why boys are less engaged in reading than girls have been offered in the literature. Gender gaps in non-cognitive skills might be affected by biological differences in brain structure and function between boys and girls, but empirical evidence on the linkages between these differences and reading performance is lacking (OECD, 2010a). A country's culture towards gender roles can also influence the relative performance of girls and boys in maths and reading (Guiso et al., 2008; Kane and Mertz, 2012; Fryer and Levitt, 2010). Different patterns of socialization might, for example, push boys to consider reading as a feminine activity (and girls to consider maths as a masculine activity). 
41. Engagement of parents during the early years of primary school can also play a role in determining reading outcomes. The 2009 PISA survey, through its parental questionnaire, offers insights on the role of parental interaction in reading performance. Reading performance at age 15 is significantly stronger among students whose parents used to read to them in the early years of primary school (OECD, 2012c). Across countries, fathers are less likely than mothers to read to their children, but overall parents show more or less the same amount of involvement in the education of their sons and that of their daughters. However, as discussed above, boys might benefit more from parental involvement than girls (Bertrand and Pan, 2011); PISA data also suggest that boys whose fathers used to read to them harbour more positive attitudes towards reading.

42. Performance in mathematics at age 15 is also characterized by gender differences, but these differences are less systematic and smaller in size compared to gender differences in reading. Boys perform better in mathematics than girls in the majority of PISA participating countries; the average OECD score in mathematics is 501 for boys and 490 for girls. But, contrary to what was observed for reading, the gender gap is not significant in all countries. Out of the 41 OECD and EU countries shown in Figure 24, the gender gap in maths is statistically significant, and negative in 29 countries. In Lithuania, the gap is actually in favour of girls and statistically significant at 6.7 score points. Boys have the largest advantage in mathematics (over 20 score points) in Belgium, Chile, the United Kingdom and the United States.

Figure 24. Gender differences in PISA mathematics performance, 2009

PISA score points - Mathematics
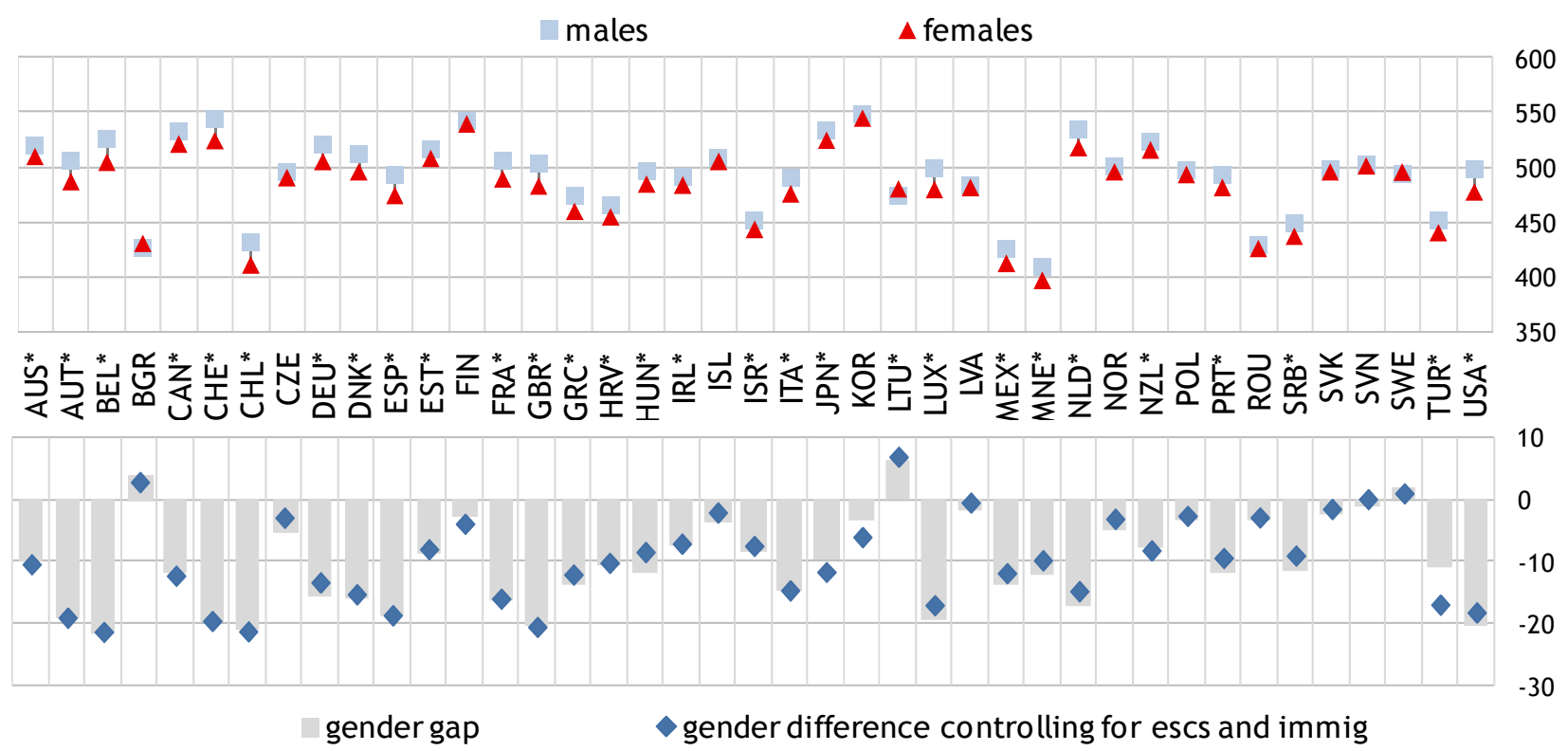

Note: The score difference is defined as girls score - boys score. Countries where gender gaps are statistically significant are identified by the symbol *.

Source: OECD PISA 2009.

43. Mathematics achievements among students in $4^{\text {th }}$ grade were surveyed in TIMSS, the Trends in International Mathematics and Science Study. The 2011 data showed little gender differences in mathematics achievements (Figure 25). A comparison between TIMSS $4^{\text {th }}$ grade and PISA would suggest that gender gaps in mathematics arise early in primary education and increase as students advance, but the mathematics achievements in $8^{\text {th }}$ grade (also surveyed in TIMSS) actually show an overall gender gap in mathematics achievements in favour of girls thus contradicting the hypothesis that gender gaps in mathematics increase as students grow older. However, using different data following a US-nationally 
representative sample of children from kindergarten through fifth grade, Fryer and Levitt (2010) find an increasing trend in gender gaps in mathematics, showing that girls and boys have equivalent performances in mathematics and reading when they enter early-childhood education (kindergarten), but girls' maths performances is 0.2 standard deviation points behind that of boys by the end of fifth grade.

Figure 25. Math performance by gender in 4th and 8th grade

Math performance by gender in 4th grade 8th grade

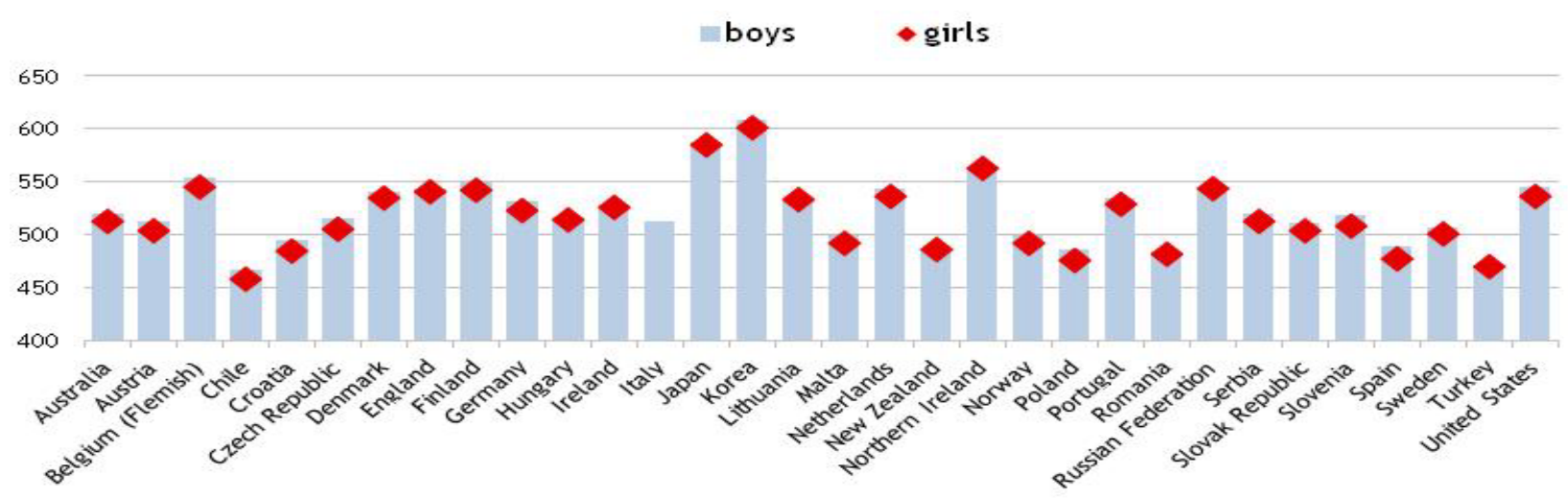

Gender gaps in math performance in $4^{\text {th }}$ and $8^{\text {th }}$ grade

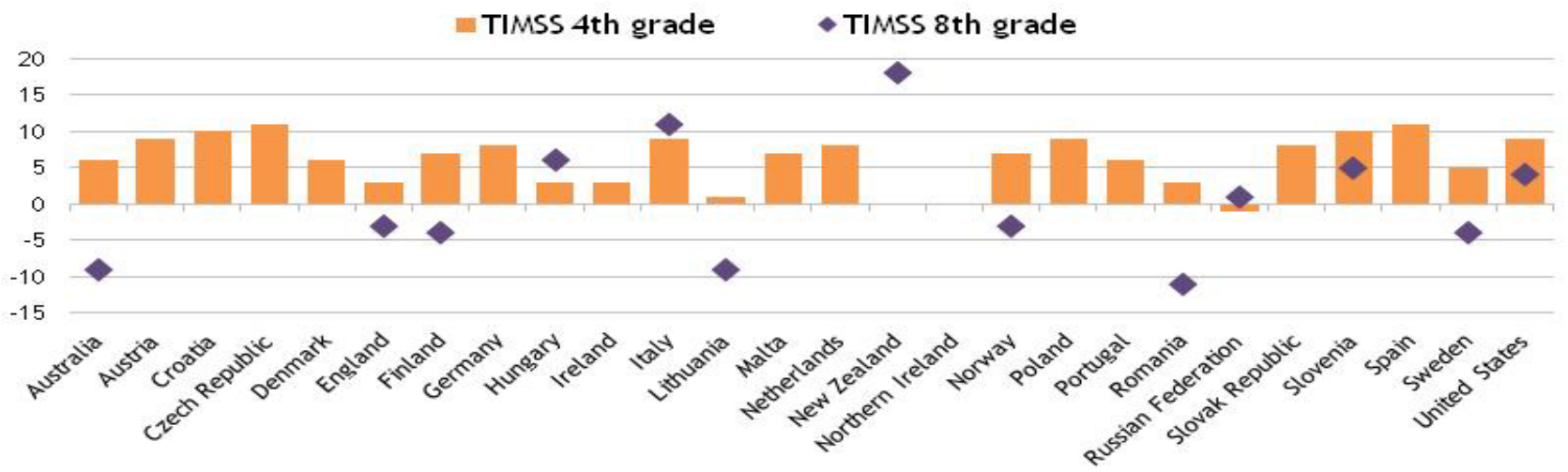

Source: International Association for the Evaluation of Educational Achievement, 2012, TIMSS 2011 International Results in Mathematics.

44. A wide range of theories have been explored to explain the observed gender gaps in mathematics performance, including - as for the literature investigating gender differences in reading performance - the role of social interactions and the role of innate biological differences, such as differences in spatial ability and brain development (for example Wilder and Powell, 1989). While these elements typically differ by gender, they fail to explain the gender gap in mathematics performance (Fryer and Levitt, 2010). On the other hand, gender gaps in mathematics performance can in part be explained by gender differences in the perception and attitudes towards mathematics as measured in the 2003 PISA survey.

45. Male students express significantly higher interest and enjoyment in mathematics compared to girls. On average in the OECD, $41 \%$ of boys and $35 \%$ of girls enjoy doing mathematics, while $58 \%$ of the boys compared to $51 \%$ of the girls are interested in the things they learn in maths. Gender gaps in the enjoyment of mathematics index were especially large in Austria, Germany and Switzerland; among the OECD and EU countries, only in Iceland, Ireland, Portugal and Spain were the gender gaps in the enjoyment of mathematics not statistically significant. Gender differences in instrumental motivation to learn mathematics - that is the relevance of mathematics reported by students to their own life - are even 
larger. Similarly, in most countries, female students tend to report lower self-efficacy in mathematics (i.e. self-reported ability to handle tasks correctly), lower self-concepts (self-reported beliefs in their own academic abilities) and higher anxiety towards mathematics. These differences are large compared to observed differences in math performance; across the OECD 1.5\% of the variance in student performance in mathematics was explained by students' interest in and enjoyment of this subject. There are a number of countries where this proportion is much larger (11\% in Finland, $15 \%$ in Korea, and $16 \%$ in Norway).

Figure 26. Gender gaps in attitudes towards mathematics, PISA 2003

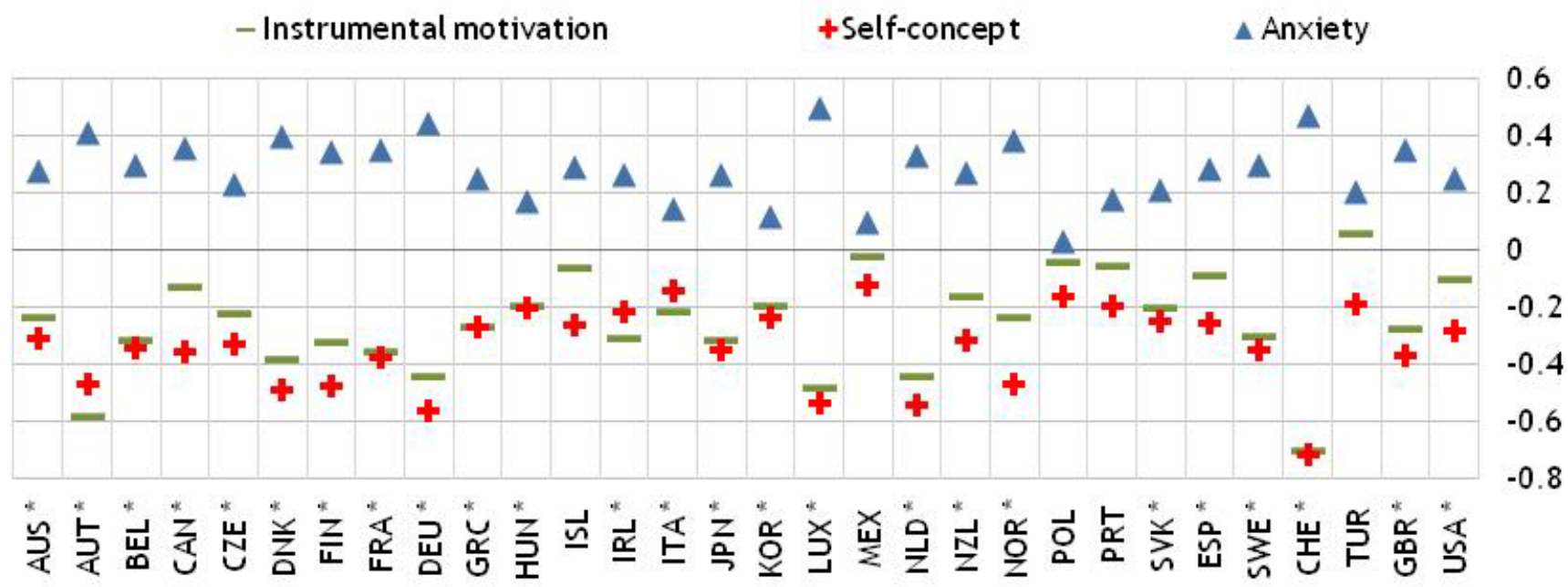

Note: Gender gaps are defined as girls' score - boys' score in each of the presented indexes. The index of instrumental motivation in mathematics is measured by a series of questions on the perceived value of studying mathematics for external rewards. The index of self-concept in mathematics is measured by a series of question on students' perceptions of how good they are at mathematics. The index of mathematics anxiety is measured by a series of questions on the level of anxiety associated with doing mathematics problems. Countries where gender gaps in instrumental motivations are statistically significant at the $95 \%$ level are identified by the symbol *. Gender gaps in self-concept in mathematics are significant at the $95 \%$ level in every country except Iceland. Gender gaps in mathematics anxiety are significant at the $95 \%$ level in every country.

Source: PISA 2003.

46. Gender differences in science performance, as measured by PISA 2009 and the previous waves, show no consistent pattern (Figure 27): they are much narrower than in mathematics and reading for all countries, and in most countries they are not statistically significant. In fact, the average gender gap in science performance across the OECD is zero. Girls have the largest advantage in Bulgaria (20 score points) followed by Lithuania, Finland and Slovenia whereas boys have the largest advantage in the United States (14 score points), Denmark, the United Kingdom and in Chile. The PISA 2006 survey, which focused on sciences, shows that there are no entrenched gender patterns in attitudes towards sciences across countries. The only dimensions where systematic gender differences can be observed are explaining phenomena scientifically, where male students outperform female students, and identifying scientific issues, where female students outperform male students. 
Figure 27. Gender differences in PISA science performance, 2009

PISA score points - Science

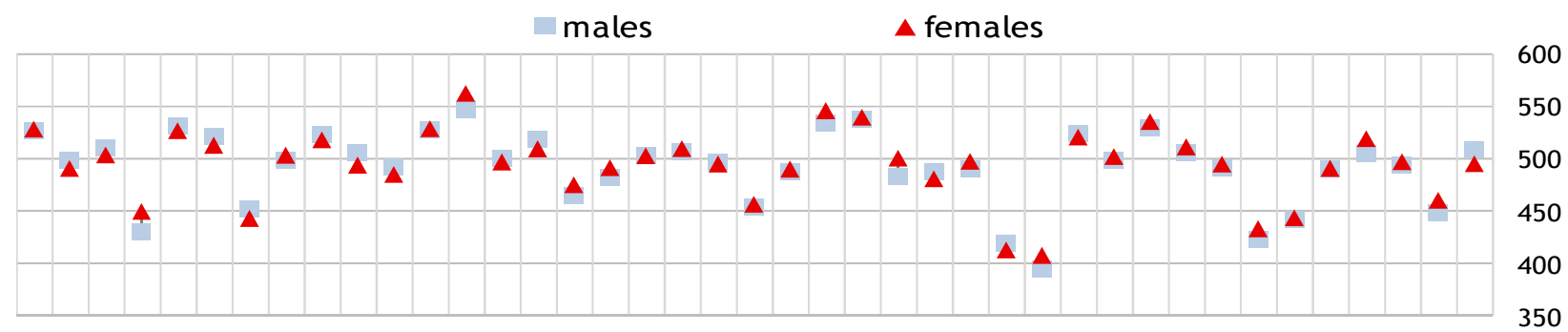

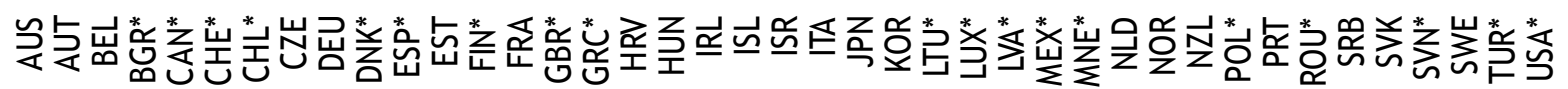

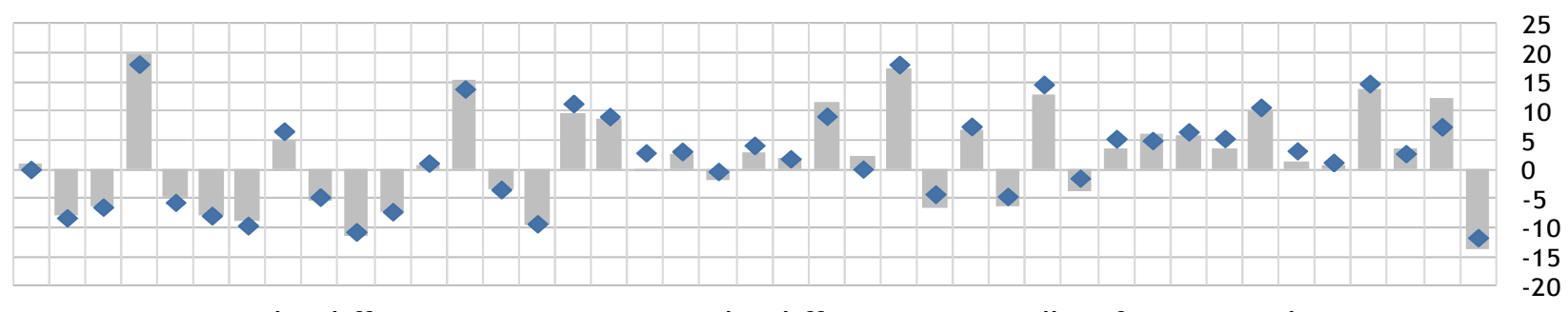

gender difference

gender difference controlling for escs and immig

Note: The score difference is defined as girls score - boys score. Countries where gender gaps are statistically significant at the $95 \%$ level are identified by the symbol *.

Source: OECD PISA 2009.

47. In all three domains - reading, mathematics and science - gender differences are much larger among the lowest and the highest performers than among the average performers (Figure 28). Gender gaps in reading are larger among under-achieving students, so it's mainly boys who lack basic reading skills. In mathematics, gender gaps are instead larger among top-performing students, thus girls are underrepresented among high-achieving students in mathematics. Finally, in science there are more girls than boys among under-achieving students and more boys than girls in top-performing students.

Figure 28. Gender gap in PISA score points by performance level, 2009

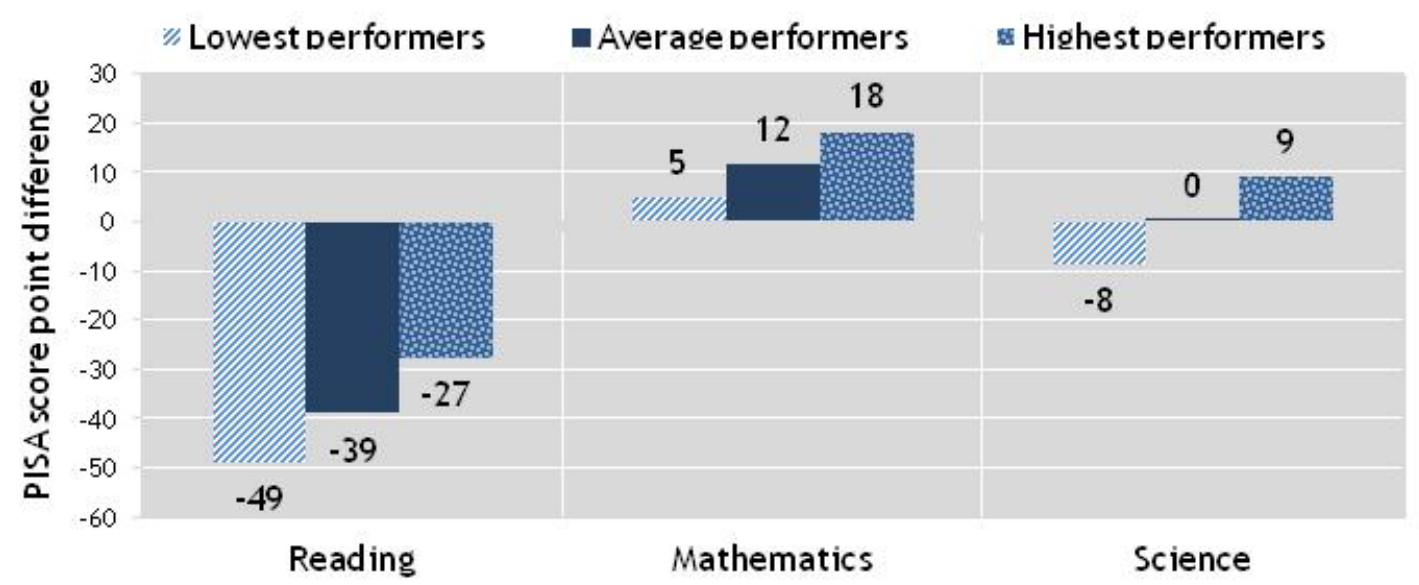

Note: the gender gap is defined here as boys' scores minus girls' scores in each subject.

Source: OECD PISA 2009. 


\section{Gender gaps in performance and gender gaps in tertiary education participation and subject choice}

48. In order to properly assess whether and how much gender differences in performance in mathematics and reading or gender differences in attitudes towards these subjects affect the choice of field of study, longitudinal data needs to be used. The longitudinal component of the PISA surveys (hereafter "PISA-L") - which follow-up students who took the PISA test until the age of 20 to 24, depending on the country - is one of the few sources of such data, but it has only been conducted in Australia, Canada, the Czech Republic, Denmark, Switzerland and Uruguay.

49. The PISA-L studies show that students who have strong competencies in reading, mathematics and sciences at age 15 - as measured by PISA - have substantially better outcomes in terms of completion of secondary education and participation in higher education, even after controlling for other student background characteristics thus indicating that strong competencies can overcome the effects of disadvantaged socio-economic backgrounds (OECD, 2012d). High reading scores are strongly associated with a higher likelihood of participating in tertiary education (OECD, 2012d); low achieving readers - and especially boys - are also more likely than other students to drop out of secondary school. Tackling the causes of boys' underperformance in reading might therefore also help improve their educational attainment. Proficiency in mathematics is also significantly associated with educational attainment; boys with high maths proficiency are more likely to attend tertiary education while girls with low maths proficiency are less likely to attend tertiary education, once socio-economic and immigrant background are taken into account (OECD, 2012d). Finally, Sikora and Pokropek (2012) show that a strong performance in sciences as measured by PISA, net of students' socio-economic and immigrant background, is significantly correlated to aspirations for higher status occupations among 15-year old.

50. At the aggregate level, gender gaps in mathematics performance do not appear to be strongly correlated with the observed gender gaps in participation in scientific fields of study in tertiary education. In fact, cross-country comparisons show very little correlation between the average performance of 15year-old girls in mathematics and the proportion of degrees in computing or engineering awarded to women. On the other hand, gender gaps in participation in scientific fields in tertiary education are much more strongly correlated to gender differences in mathematics self-concept among 15-year-old students (Figure 29).

Figure 29. Women in computing vs. maths performance and maths self-concept
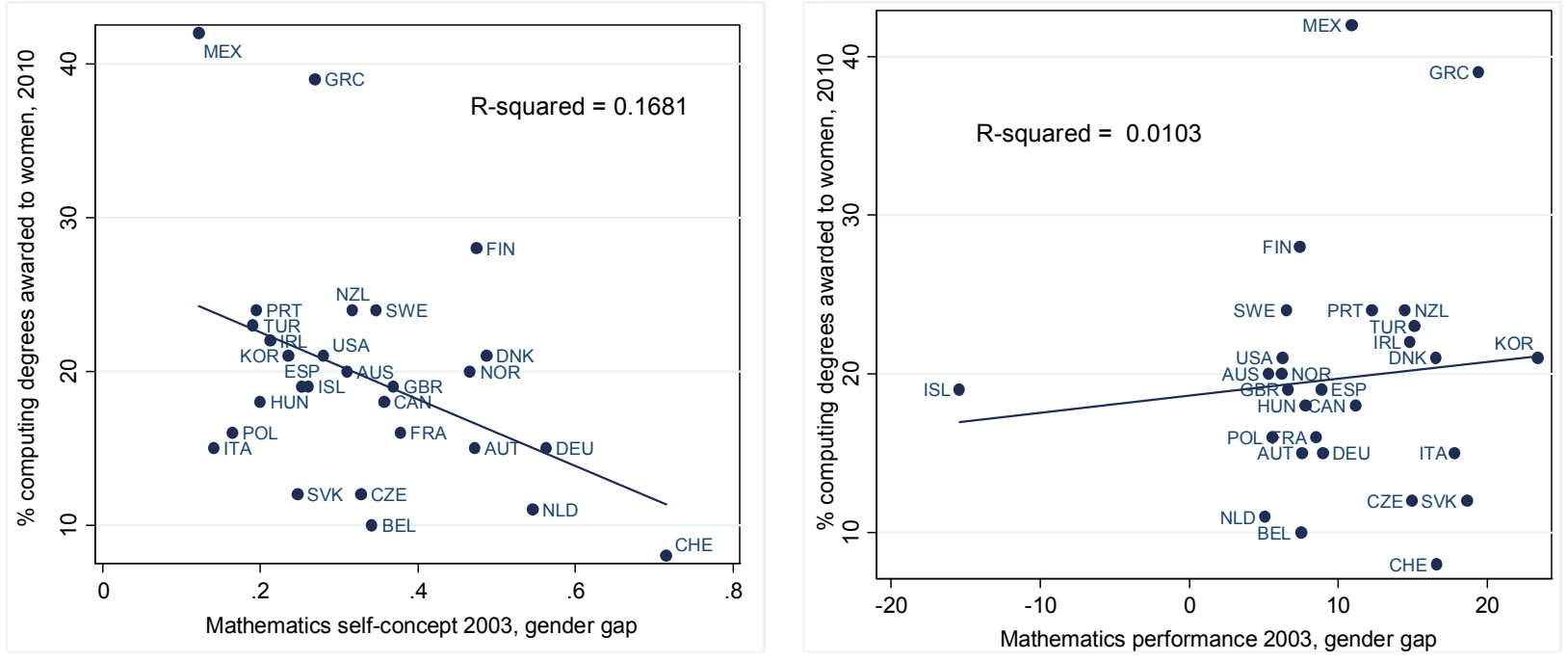

Source: PISA 2009 and EAG 2012. 
51. The PISA-L studies show that performance in subjects such as mathematics, science or reading remains a strong determinant of subjects chosen in post-secondary education. But the role of reading, maths and sciences performance in driving gender gaps in the field of study chosen, is mediated by the observed gender differences in motivation, enjoyment and self-concept towards these subjects. In Australia, for example, the results clearly show that instrumental motivation to learn mathematics (that is the relevance of mathematics reported by students to their own life) is a more important motivator for a career in physical sciences or computing for young men than for young women. In particular, for a one standard deviation increase in the instrumental motivation score, the change in the likelihood of enrolling in a physical science course is around 6 percentage points higher for males than for females. Beliefs about self-efficacy in mathematics are also shown to affect the choice of physical science and computing more for men than women. Similar results are found in the Czech Republic PISA-L study.

52. A number of studies (Ipsos Reid, 2010; Parvin and Porter, 2008; OECD, 2008) discuss the important role of teachers' attitudes in shaping students' attitudes towards subjects, be it reading, sciences or mathematics. At the same time, students' interest in sciences appears to decline significantly as they grow up. It is therefore important to train teachers to provide an interesting context and present career options for these subjects early on, to address gender-specific attitudes within the classroom and to introduce gender mainstreaming concepts in teaching material.

\section{Career aspirations}

53. In tertiary education students choose their field of study also based on their aspirations in terms of occupation, earnings and working conditions. Disentangling the role of career aspirations from the role of ability and previous academic achievements in determining the choice of field of study is very difficult, both for methodological and data availability reasons. Studies that look at the role of expected earnings in determining the choice of field of study find a positive but small correlation (Beffy et al., 2012; Flabbi, 2011; Flabbi and Tejada, 2012). Empirical evidence on other labour market outcomes that might enter into play in this type of decision, such as working hours and working conditions, is still lacking due to data restrictions (see for example Flabbi and Tejada, 2012).

54. Sikora and Pokropek (2012), using the PISA 2006 survey, show that gender segregation in career expectation is already observable at age 15, well before entry in tertiary education. As shown in Figures 30 and 31, across PISA-participating countries, 15-year-old girls were consistently more likely than boys to expect professional careers ${ }^{3}$ in biology, agriculture or health, whereas boys were more likely to expect careers in computing, engineering or mathematics. Gender differences in career expectations exist even among top performing students, which are in fact as large as those of the rest of the students.

\footnotetext{
${ }^{3}$ These data are based on the answers to the question "What kind of job do you expect to have when you are about 30 years old?" in the 2006 PISA survey.
} 
Figure 30. Percentage of 15 -year-old boys and girls planning a career in engineering and computing

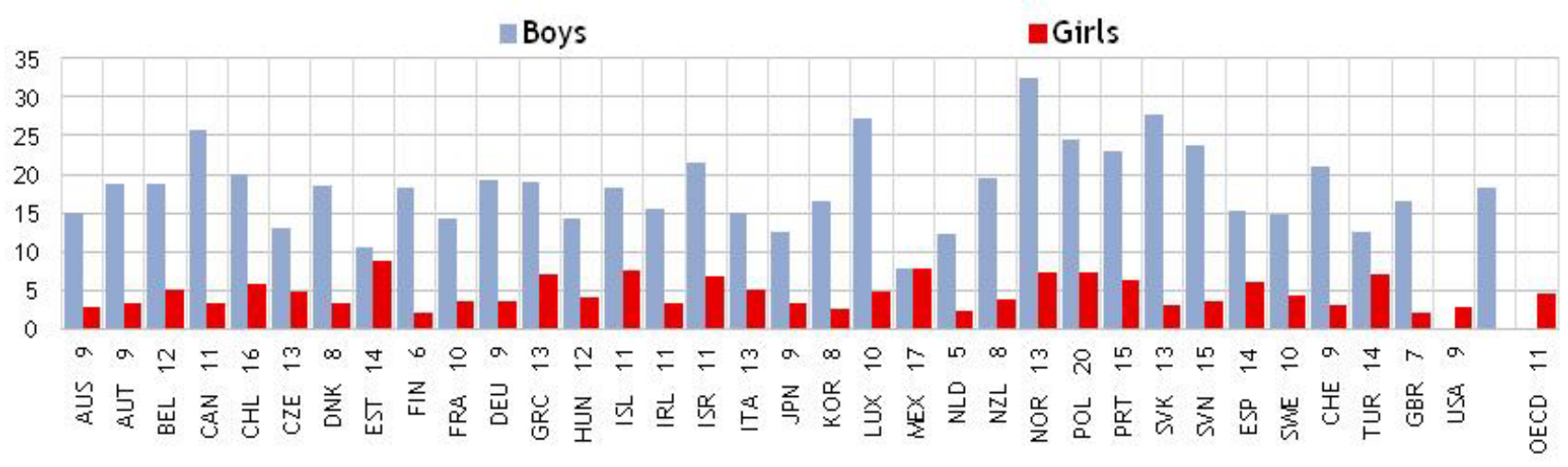

Note: the number next to the country code indicates the Percentage of all 15-year-old students who plan a career in engineering or computing.

Source: Sikora and Pokropek (2012).

Figure 31. Percentage of 15-year-old boys and girls planning a career in health services

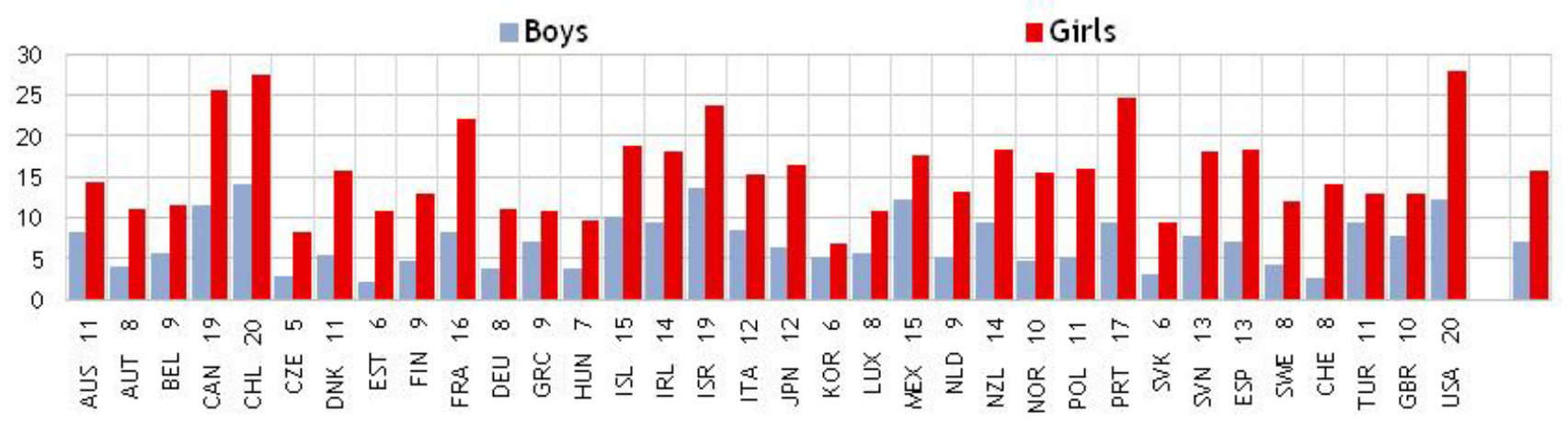

Note: the number next to the country code indicates the Percentage of all 15-year-old students who plan a career in health services.

Source: Sikora and Pokropek (2012).

55. PISA performance in sciences, attitudes towards sciences at age 15 and, to a lesser degree, the students' socio-economic background all increase the likelihood of aspiring to a career in computing, engineering or mathematics. On the other hand, gender differences in science performance fail to explain gender gaps in career expectations in these fields, even when course work, family background, parental occupation and education are taken into account (Sikora and Pokropek, 2012). These findings, consistently observed across countries, suggest that cultural factors and norms are at play.

56. The PISA-L study for Australia ${ }^{4}$ shows that, in addition to being less likely to aspire to careers in computing, engineering or mathematics, girls are also less likely to realize these aspirations: only $26 \%$ of women who aspire to a career in physical science, mathematics and computing at age 15 actually undertake tertiary courses in these fields compared to $60 \%$ for males. The polarization of fields of study is further reinforced in the transition from higher education to employment. As shown in Figure 32, about 66\% of female university graduates in humanities work as teachers, compared with about $53 \%$ of male graduates. Conversely, $71 \%$ of male graduates from the science field work as professionals in physics, mathematics and engineering, as opposed to $43 \%$ of female graduates (Flabbi and Tejada, 2012).

\footnotetext{
${ }^{4}$ In the other PISA-L studies samples were not large enough to allow for this level of disaggregation in the data.
} 
Figure 32. Men and women who graduated in the same field often make different occupational choices

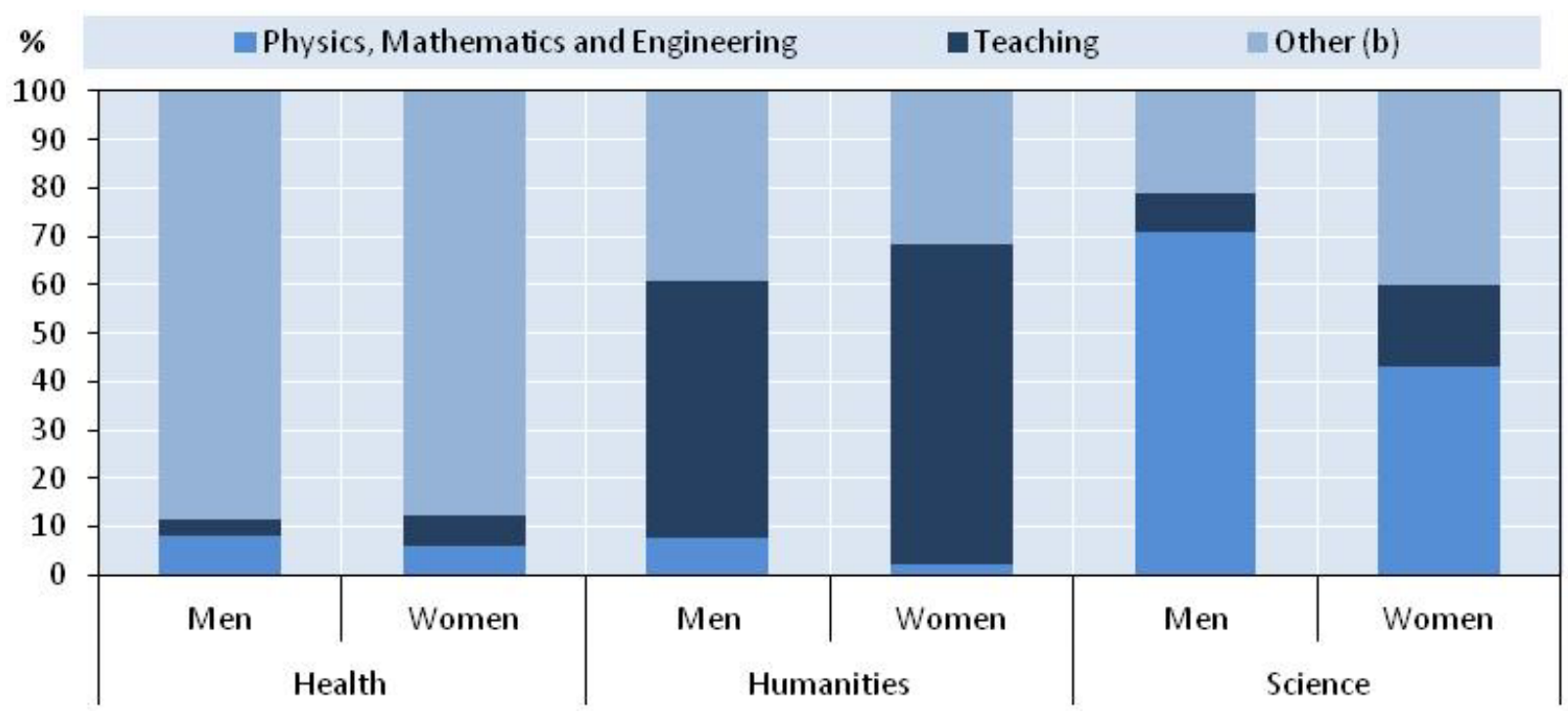

Note: distribution of graduates from higher education (ISCED 5A) who work as professionals or technicians and have about five years of work experience after leaving higher education in 14 OECD countries (Austria, the Czech Republic, Estonia, Finland, France, Germany, Italy, Japan, the Netherlands, Norway, Portugal, Spain, Switzerland and the United Kingdom).

Source: Flabbi and Tejada, 2012.

\section{Additional factors driving gender differences in subject choice}

57. In addition to performance and attitudes in secondary education, the economic literature identifies a number of additional factors that can explain the gender differences observed across the OECD and EU countries in the field of study chosen by students in tertiary education.

58. Family background is one of the most powerful and consistent predictors of educational attainment and aspirations (Schoon \& Parsons, 2002; Knight et al., 2011; Hertz et al., 2008). Analyses of the PISA-L data show that parental occupation and immigrant status do influence the pattern of subjects chosen by girls and boys, but there is variation across the five countries covered (Australia, Canada, the Czech Republic, Switzerland and Uruguay) in the types of occupations and how they might influence the choice of boys or of girls. In most cases boys appear to be more affected than girls by socialisation within the family (see also Bertrand and Pan, 2011).

59. Pressure from peers might also have a significant effect on the choice of field of study, as shown by De Giorgi, Pellizzari and Redaelli (2010). Given that girls are more likely to graduate in humanities rather than in scientific subjects, girls considering majoring in the latter might be diverted by their peers with adverse consequences on academic performance, entry wages and job satisfaction. Evidence on the role of peers influence in shaping gender gaps in orientations towards STEM fields is also found by Legewie and DiPrete (2012) for the United States.

60. There is little evidence that student-teacher gender matching improves students' performance (Cho, 2012; Winters et al., 2013) while it might affect students attitudes towards the subject. Beilock et al., (2010) show, for example, that a teacher's anxiety towards mathematics is correlated to maths anxiety among female students but not among male ones - even when controlling for teachers' math knowledge. As a result, through the role of students' attitudes towards maths in their performance, teachers' math anxiety affects girls' maths performance (see Section 5). 
61. Tracking in education systems can further entrench existing gender differences in preferences for fields of study, as vocational education often prepares pupils for male-dominated professions. The PISA-L studies for Australia, the Czech Republic and Switzerland show that boys are more likely than girls to attend vocational schools, because these prepare for the typically 'male' professions and because boys are more likely than girls to perceive vocational education as "scientific". Girls who do not earn high enough grades to pursue a technical subject at university do not perceive vocational training as an alternative education path and often compromise their subject choice to get access to university.

\section{Gender differences in the teaching profession}

62. In OECD and European countries, teaching is a female-dominated occupation. On average in the OECD countries women account for about two-thirds of teachers and academic staff (OECD, 2012a). However the prevalence of women among teachers declines at each successive level of education; in fact, in tertiary education women are no longer the majority. Women account for $97 \%$ of teachers in earlychildhood education, $83 \%$ in primary education, $68 \%$ at the lower secondary level, $56 \%$ at the upper secondary level and $41 \%$ at the tertiary level (Figure 33 ).

63. The data show significant variations across countries, at each level of education. Japan, Korea, Switzerland, Turkey and - to a lesser degree - Germany, Luxembourg, Norway and Spain have a higherthan-average share of male teachers in primary education. On the other hand, men account for $5 \%$ or less of teachers at this level in the Czech Republic, Italy and Slovenia. In tertiary education, women are better represented in teaching and academic staff in Canada, Finland and New Zealand while they are below the OECD average in Japan, Korea and Switzerland (where they account for less than $20 \%$ of teachers).

Figure 33. Proportion of women among teachers, at various level of education

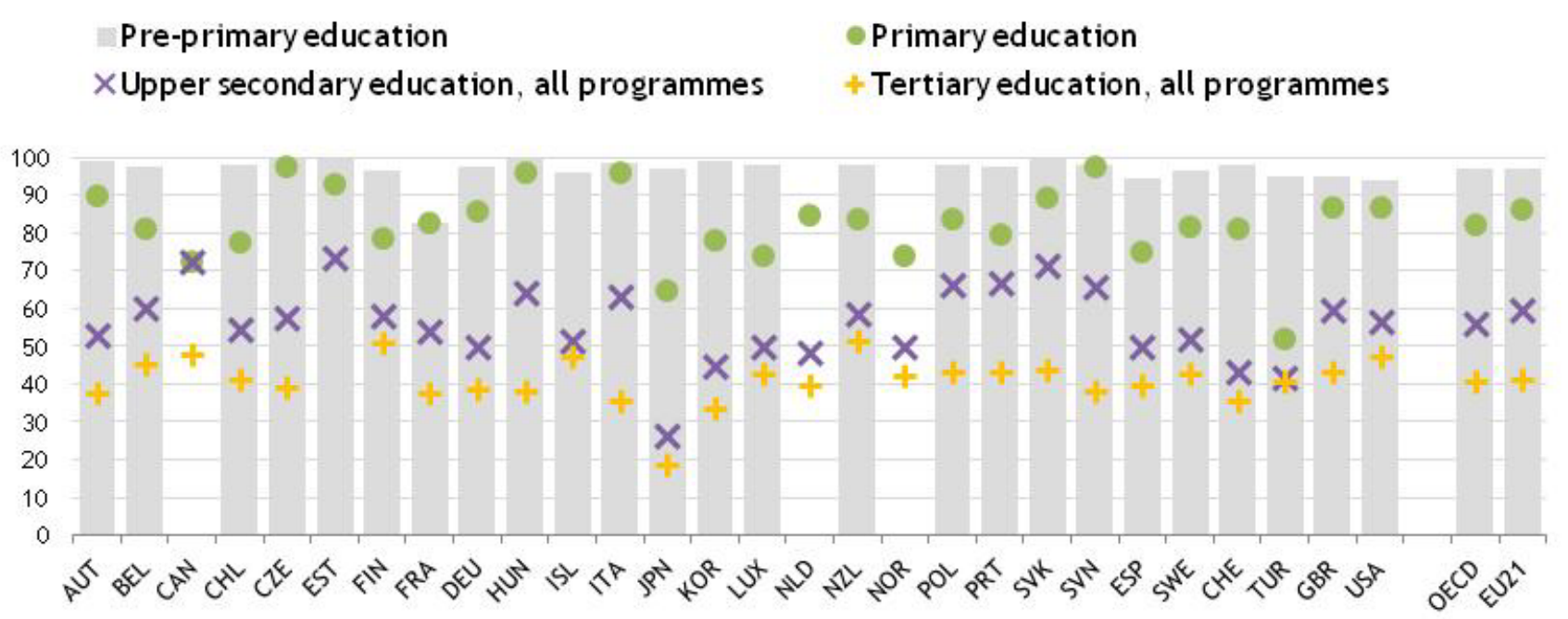

Source: OECD 2012, EAG.

64. The quality of teachers and teaching is the most significant input in improving students' performance (OECD, 2010b; OECD, 2012a). An under-representation of men in this profession is likely to hinder this goal by reducing the supply of candidates. Making the teaching profession more appealing, providing teachers with career and professional development opportunities, and providing high-quality training for teachers would help in recruiting the most talented candidates and possibly attract more men to go into the teaching profession. 
65. Addressing men's under-representation in the teaching profession is sometimes also proposed as a potential way to improve student outcomes among boys, under the assumption that same-gender teachers might serve as better role models (Dee, 2007). While there is no conclusive empirical evidence that gender matching between teachers and students improves academic performance (Winters et al., 2013), there are indications that it can affect students' attitudes towards certain subjects (see Section 5); further analysis is needed to understand the long-term consequences of gender imbalances in the teaching profession.

\section{Conclusions and policy implications}

66. Over the past decades, educational attainment among women has increased significantly and more rapidly than among men in the OECD and EU countries. As a result, in most of these countries, gender inequality in educational attainment has closed or even reversed and women nowadays account for the majority of tertiary-type A graduates. Despite their progress in obtaining university degrees, women are still opting for "traditional" fields of study. They account for the vast majority of graduates in education and in health and welfare, while they represent a minority in fields like engineering and computer sciences. In the past decade, there has only been a very marginal reduction in horizontal segregation in education, driven by women entering male-dominated fields of study more than men entering female-dominated fields of study.

67. This paper has presented a number of factors that explain gender differences in education and their trends in OECD countries. The closing and reversal of gender gaps in attainments are mainly due to higher participation and more successful completion of tertiary degrees among women, driven by improved prospects of participation in the labour market for women and by demographic changes. The under-performance of boys in participation and completion of upper secondary and post-secondary education is another contributing factor. In all OECD countries boys lag behind in reading skills and in most countries they tend to have poorer school performance, higher repetition rates and more irregular attendance than girls. Coming from a disadvantaged socio-economic background significantly increases the likelihood of poorer performance in school, especially among boys, who are found to respond more than girls to parental input. Poorer aspirations among boys reinforce their disadvantage in educational attainment. This paper has presented data illustrating that attitudes, interest and self-perceptions towards academic subjects explain a significant part of gender differences in education performance and career expectations.

68. To the extent that they are not explained by innate differences in preferences, these systematic gender disparities in education involve a loss of efficiency - as talents are not allocated at their best - and a loss of opportunities at the individual level, for both men and women. Addressing gender gaps in education will require a change in attitudes and behaviours not only among students, but also among teachers, parents and the society at large; this will require time, as cultural factors are not easy to influence. Nevertheless, policy can help.

69. Raising awareness among parents, teachers and students about the role of stereotypes can yield results in the long term, especially if interventions start early in the students' life, before stereotypical perceptions and attitudes towards what boys and girls excel in doing and enjoy set in (OECD, 2010c; OECD 2012b). Providing high-quality training and guidelines to teachers on how to develop genderspecific teaching methods and material will also help in improving students' self-concept and interest in the various subjects. Career counselling in schools and mentoring programmes can be introduced from a young age to challenge girls' and boys' perceptions of gender stereotypes and open alternative career paths. Promoting role models and offering extra-curricular activities in specific fields can also help girls interested in pursuing male-dominated fields of study and careers, and interested boys in pursuing femaledominated careers. 
70. To help reduce gender inequality in education attainment and performance, a number of measures can be adopted. Providing high-quality early education, especially to children from disadvantaged backgrounds, and providing sufficient support to students from single-parent families will benefit both boys and girls, while yielding greater gender equality since boys are more reactive to equal levels of investments. Improving boys' performance and interest in reading is also an important element, which can be achieved by adapting and diversifying reading material in order to appeal to boys as well as to girls. In countries where tracking systems reinforce gender segregation in subject areas, greater flexibility in transferring between vocational and university tracks can open more career possibilities for both girls and boys.

71. While many countries have implemented initiatives to challenge gender inequalities and gender stereotypes in education, a more comprehensive framework for these interventions is needed (European Commission, 2010) and efforts from governments, schools and the private sector should be coordinated. More attention should also be paid by policy makers to the important role of parents in challenging gendered attitudes towards education.

72. In the OECD and European countries, teaching is a female-dominated occupation, but the prevalence of women declines at each successive level of education. More can be done to make the teaching profession more attractive to the most talented candidates and to men. Teachers' attitudes have an important role in shaping students' attitudes. It is therefore important to train teachers to address genderspecific attitudes within the classroom, introduce gender mainstreaming concepts in teaching material and provide an interesting context for various subjects early on.

73. While the stylized facts and empirical evidence reviewed in this paper offer a strong case for the role of attitudes, norms and stereotypes in shaping gender differences in education, more empirical work will need to be developed, especially in cross-country comparisons, to understand how large these effects are and how they interact with exogenous conditions. More analysis on the role of labour market conditions in shaping the choice of the field of study also needs to be developed. Availability of relevant data is still often an obstacle and policy makers need to consider the importance of developing this type of information to identify the policies that can most effectively promote growth and innovation by improving gender equality in education outcomes. 


\section{BIBLIOGRAPHY}

Beffy, M., D. Fougère, and A. Maurel (2012), "Choosing the Field of Study in Postsecondary Education: Do Expected Earnings Matter?” The Review of Economics and Statistics, Vol. 94/1, pp.334-347.

Beilock, S., E. Gunderson, G Ramirez, S. Levine (2010), "Female teachers' math anxiety affects girls' math achievement" Proceedings of the National Academy of Sciences, Vol. 107/5, pp.1860-1863.

Chiappori, P-A, M. Iyigun, Y. Weiss (2009), "Investment in schooling and the marriage market", American Economic Review, Vol. 99, pp.1689-1713.

Cho, I. (2012), "The effect of teacher-student gender matching: Evidence from OECD countries" Economics of Education Review, Vol. 31, pp.54- 67.

Dee, T. S. (2007), "Teachers and the gender gaps in student achievement" Journal of Human Resources, Vol. 42/3, p.528.

Diprete, T., C. Buchmann (2006), "Gender-specific trends in the value of education and the emerging gender gap in college completion," Demography, Vol. 43/1, pp.1-24.

European Commission (2010), Gender Differences in Education Outcomes. Study on the Measure Taken and the Current Situation in Europe, Brussels.

Fernandez, T., M. Bucheli and S. Cardozo (2012), "Gender Differences in the Transition from Secondary to Post-secondary Education: The Case of Uruguay: A PISA Longitudinal Study", Background study for the OECD Gender Initiative.

Finnie, R., S. Childs and A. Wismer (2012), "Gender Differences in Higher Education and Labour Market Activity at age 20 in Canada", Background study for the OECD Gender Initiative.

Fryer, R. and S. Levitt (2010), "An Empirical Analysis of the Gender Gap in Mathematics" American Economic Journal: Applied Economics, Vol. 2, pp.210-240.

Goldin G., and L. F. Katz (2002), "The Power of the Pill: Oral Contraceptives and Women's Career and Marriage Decisions", Journal of Political Economy, Vol. 110/4, pp.730-770.

Goldin G. (2006), "The Quiet Revolution That Transformed Women's Employment, Education, and Family", American Economic Review, Vol. 96/2, pp.1-21.

Goldin G., L. F. Katz, and I. Kuziemko (2006), "The Homecoming of American College Women: The Reversal of the College Gender Gap", Journal of Economic Perspectives, Vol. 20/4, pp.133-156.

Guiso, L., F. Monte, P. Sapienza, and L. Zingales (2008), “Culture, Gender, and Math”, Science, Vol. 320, pp.1164-1165. 
Hanushek, E.A and L. Woessmann (2006), "Does Educational Tracking Affect Performance and Inequality? Differences-in-Differences Evidence across countries", The Economic Journal, No 116, pp.C63-C76.

Hupka-Brunner, S., S. Kanji, M. M. Bergman and T. Meyer (2012), "OECD report on gender differences in the transition from secondary to post-secondary education in Switzerland", Background study for the $O E C D$ Gender Initiative.

Kane J., J. Mertz (2012), "Debunking Myths about Gender and Mathematics Performance”, Notices of the American Mathematical Society, Vol. 59/1, pp.10-21.

Legewie, J. and T. DiPrete (2012), "School Context and the Gender Gap in Educational Achievement", American Sociological Review, Vol. 77/3, pp.463-485.

Matějů, P., P. Soukup, J. Straková and M. Smith (2012), "Gender Differences in the Transition from Secondary to Post-secondary Education: The Case of the Czech Republic", Background study for the $O E C D$ Gender Initiative.

McDaniel, A., (2010), "Cross-National Gender Gaps in Educational Expectations: The Influence of National Level Gender Ideology and Educational Systems", Comparative Education Review, Vol. 54/1, pp.27-50.

Paglin, M., and A. Rufolo (1990), "Heterogeneous Human Capital, Occupational Choice, and Male-Female Earnings Differences" Journal of Labor Economics, Vol. 8/1, pp.123-44.

Pekkarinen, T. (2012). "Gender differences in education", Nordic Economic Policy Review, Vol. 1, pp.131.

IEA (2011). International Results in Reading, PIRLS 2011, TIMSS \& PIRLS International Study Center, Amsterdam.

IEA (2011). International Results in Mathematics, TIMSS 2011, TIMSS \& PIRLS International Study Center, Amsterdam.

Osborne, J., S. Simon and S. Collins (2003), "Attitudes towards science: A review of the literature and its implications", International Journal of Science Education, Vol. 23/9, pp.1049-1079.

Polidano, C. and Ryan, C. (2012). "Gender Differences in the Transition from Secondary to Postsecondary Education: The Case of Australia". Background Paper for the OECD Gender Initiative.

OECD (2008), Encouraging Student Interest in Science and Technology Studies, Global Science Forum, OECD Publishing, Paris, DOI: http://dx.doi.org/10.1787/9789264040892-en.

OECD (2010a), PISA 2009 Results: Learning to Learn - Student Engagement, Strategies and Practices (Volume III), OECD Publishing, Paris, DOI: http://dx.doi.org/10.1787/9789264083943-en.

OECD (2010b), Strong Performers and Successful Reformers in Education, Lessons from PISA for the United States, OECD Publishing, Paris, DOI: http://dx.doi.org/10.1787/9789264096660-en.

OECD (2010c), PISA 2009 Results: What Students Know and Can Do - Student Performance in Reading, Mathematics and Science (Volume I), OECD Publishing, Paris. 
OECD (2011), Education at a Glance 2012: OECD Indicators, OECD Publishing, Paris.

OECD (2012a), Education at a Glance 2012: OECD Indicators, OECD Publishing, Paris, DOI: http://dx.doi.org/10.1787/eag-2012-en.

OECD (2012b), Closing the Gender Gap: Act Now, Paris, OECD Publishing, http://dx.doi.org/10.1787/9789264179370-en.

OECD (2012c), Let's read them a story, PISA, OECD Publishing, Paris.

OECD (2012d), Pathways to Success, PISA, OECD Publishing, Paris.

OECD (2012e), Grade Expectations How Marks and Education Policies Shape Students' Ambitions, PISA, OECD Publishing, Paris.

Sikora, J. and A. Pokropek (2011), "Gendered Career Expectations of Students: Perspectives from PISA 2006”, OECD Education Working Papers, No. 57, OECD Publishing. http://dx.doi.org/10.1787/5kghw6891gms-en.

Sikora, J., A. Pokropek (2012), "Gender Segregation of Adolescent Science Career Plans in 50 Countries", Science Education, Vol. 96/2, pp.234-264.

Thévenon, O., N. Ali, W. Adema, A. Salvi Del Pero (2012), "Effects of Reducing Gender Gaps in Education and Labour Force Participation on Economic Growth in the OECD", OECD Social, Employment and Migration Working Papers, No. 138, OECD Publishing.

Wilder, G., K. Powell (1989), "Sex Differences in Test Performance: A Survey of the Literature", College Board Report No. 89-3. New York: College Entrance Examination Board.

Winters, M., R. Haigh, T. Swaim, K. Pickering, (2013), "The effect of same-gender teacher assignment on student achievement in the elementary and secondary grades: Evidence from panel data", Economics of Education Review, Vol. 34, pp.69-75.

Xie and Shauman (2003), Women in science - Career opportunities and outcomes, Cambridge, MA, Harvard University Press. 


\section{OECD SOCIAL, EMPLOYMENT AND MIGRATION WORKING PAPERS}

Most recent releases are:

No. 150 REDISTRIBUTION POLICY IN EUROPE AND THE UNITED STATES: IS THE GREAT RECESSION A 'GAME CHANGER' FOR WORKING-AGE FAMILIES? Herwig Immervoll, Linda Richardson (2013)

No. 149 A BIRD'S EYE VIEW OF GENDER DIFFERENCES IN EDUCATION IN OECD COUNTRIES Angelica Salvi Del Pero and Alexandra Bytchkova (2013)

No. 148 TRENDS IN POVERTY AND INEQUALITY IN DECENTRALISING INDONESIA Riyana Miranti, Yogi Vidyattama, Erick Hansnata, Rebecca Cassells and Alan Duncan (2013)

No. 147 WOMEN ENTREPRENEURS IN THE OECD: KEY EVIDENCE AND POLICY CHALLENGES Mario Piacentini (2013)

No. 146 Forthcoming

No. 145 DRIVERS OF FEMALE LABOUR FORCE PARTICIPATION IN THE OECD Olivier Thévenon (2013)

No. 144 THE ROLE OF SHORT-TIME WORKING SCHEMES DURING THE GLOBAL FINANCIAL CRISIS AND EARLY RECOVERY, Alexander Hijzen, Sébastien Martin (2012)

No. 143 TRENDS IN JOB SKILL DEMANDS IN OECD COUNTRIES, Michael J. Handel (2012)

No. 142 HELPING DISPLACED WORKERS BACK INTO JOBS AFTER A NATURAL DISASTER: RECENT EXPERIENCES IN OECD COUNTRIES, Danielle Venn (2012)

No. 141 LABOUR MARKET EFFECTS OF PARENTAL LEAVE POLICIES IN OECD COUNTRIES, Olivier Thévenon \& Anne Solaz (2012)

No. 140 FATHERS' LEAVE, FATHERS' INVOLVEMENT AND CHILD DEVELOPMENT: ARE THEY RELATED? EVIDENCE FROM FOUR OECD COUNTRIES, Maria C. Huerta, Willem Adema, Jennifer Baxter, WenJui Han, Mette Lausten, RaeHyuck Lee and Jane Waldfogel (2012)

No. 139 FLEXICURITY AND THE ECONOMIC CRISIS 2008-9 - EVIDENCE FROM DENMARK, Tor Eriksson (2012)

No. 138 EFFECTS OF REDUCING GENDER GAPS IN EDUCATION AND LABOUR FORCE PARTICIPATION ON ECONOMIC GROWTH IN THE OECD, Olivier Thévenon, Nabil Ali, Willem Adema and Angelica Salvi del Pero (2012)

No. 137 THE RESPONSE OF GERMAN ESTABLISHMENTS TO THE 2008-2009 ECONOMIC CRISIS, Lutz Bellman, Hans-Dieter Gerner, Richard Upward (2012)

No. 136 Forthcoming THE DYNAMICS OF SOCIAL ASSISTANCE RECEIPT IN GERMANY Sebastian Königs

No. 135 MONEY OR KINDERGARTEN? DISTRIBUTIVE EFFECTS OF CASH VERSUS IN-KIND FAMILY TRANSFERS FOR YOUNG CHILDREN Michael Förster and Gerlinde Verbist (2012)

No. 134 THE ROLE OF INSTITUTIONS AND FIRM HETEROGENEITY FOR LABOUR MARKET ADJUSTMENTS: CROSS-COUNTRY FIRM-LEVEL EVIDENCE Peter N. Gal (VU University Amsterdam), Alexander Hijzen and Zoltan Wolf (2012)

No. 133 CAPITAL'S GRABBING HAND? A CROSS-COUNTRY/CROSS-INDUSTRY ANALYSIS OF THE DECLINE OF THE LABOUR SHARE Andrea Bassanini and Thomas Manfredi (2012)

No. 132 INCOME DISTRIBUTION AND POVERTY IN RUSSIA Irinia Denisova (2012)

No. 131 ELIGIBILITY CRITERIA FOR UNEMPLOYMENT BENEFITS Danielle Venn (2012)

No. 130 THE IMPACT OF PUBLICLY PROVIDED SERVICES ON THE DISTRIBUTION OF RESOURCES: REVIEW OF NEW RESULTS AND METHODS Gerlinde Verbist, Michael Förster and Maria Vaalavuo (2012)

No. 129 AN OVERVIEW OF AUSTRALIA'S SYSSTEM OF INCOME AND EMPLOYMENT ASSISTANCE FOR THE UNEMPLOYED Peter Davidson, Peter Whiteford (2012) 
No. 128 THE INTEGRATION OF IMMIGRANTS AND THEIR CHILDREN INTO THE LABOUR MARKET IN SWITZERLAND Thomas Liebig, Sebastian Kohls and Karoline Krause (2012)

No. 127 THE LABOUR MARKET INTEGRATION OF IMMIGRANTS AND THEIR CHILDREN IN AUSTRIA Karolin Krause and Thomas Liebig (2011)

No. 126 ARE RECENT IMMIGRANTS DIFFERENT? A NEW PROFILE OF IMMIGRANTS IN THE OECD BASED ON DIOC 2005/06, Sarah Widmaier and Jean-Christophe Dumont (2011)

No. 125 EARNINGS VOLATILITY AND ITS CONSEQUENCES FOR HOUSEHOLDS Danielle Venn (2011)

No. 124 CRISIS, RECESSION AND THE WELFARE STATE, Willem Adema, Pauline Fron and Maxime Ladaique (2011)

No. 123 AGGREGATE EARNINGS AND MACROECONOMIC SHOCKS Andrea Bassanini (2011)

No. 122 REDISTRIBUTION POLICY AND INEQUALITY REDUCTION IN OECD COUNTRIES: WHAT HAS CHANGED IN TWO DECADES? Herwig Immervoll, Linda Richardson (2011)

No. 121 OVER-QUALIFIED OR UNDER-SKILLED Glenda Quintini (2011)

No. 120 RIGHT FOR THE JOB Glenda Quintini (2011)

No. 119 THE LABOUR MARKET EFFECTS OF UNEMPLOYMENT COMPENSATION IN BRAZIL Alexander Hijzen (2011)

No. 118 EARLY MATERNAL EMPLOYMENT AND CHILD DEVELOPMENT IN FIVE OECD COUNTRIES Maria del Carmen Huerta, Willem Adema, Jennifer Baxter, Miles Corak, Mette Deding, Matthew C. Gray, Wen-Jui Han, Jane Waldfogel (2011)

No. 117 WHAT DRIVES INFLOWS INTO DISABILITY? EVIDENCE FROM THREE OECD COUNTRIES Ana Llena-Nozal and Theodora Xenogiani (2011)

No. 116 COOKING, CARING AND VOLUNTEERING: UNPAID WORK AROUND THE WORLD Veerle Miranda (2011)

No. 115 THE ROLE OF SHORT-TIME WORK SCHEMES DURING THE 2008-09 RECESSION Alexander Hijzen and Danielle Venn (2010)

No. 114 INTERNATIONAL MIGRANTS IN DEVELOPED, EMERGING AND DEVELOPING COUNTRIES: AN EXTENDED PROFILE Jean-Christophe Dumont, Gilles Spielvogel and Sarah Widmaier (2010)

No. 113 ACTIVATION POLICIES IN JAPAN Nicola Duell, David Grubb, Shruti Singh and Peter Tergeist (2010)

No. 112 ACTIVATION POLICIES IN SWITZERLAND

Nicola Duell and Peter Tergeist with contributions from Ursula Bazant and Sylvie Cimper (2010)

No. 111 ECONOMIC DETERMINANTS AND CONSEQUENCES OF CHILD MALTREATMENT Lawrence M. Berger, Jane Waldfogel (forthcoming)

No. 110 DISTRIBUTIONAL CONSEQUENCES OF LABOR DEMAND ADJUSTMENTS TO A DOWNTURN: A MODEL-BASED APPROACH WITH APPLICATION TO GERMANY 2008-09 Herwig Immervoll, Olivier Bargain, Andreas Peichl, Sebastian Siegloch (2010)

No. 109 DECOMPOSING NOTIONAL DEFINED-CONTRIBUTION PENSIONS: EXPERIENCE OF OECD COUNTRIES'REFORMS

Edward Whitehouse (2010)

No. 108 EARNINGS OF MEN AND WOMEN WORKING IN THE PRIVATE SECTOR: ENRICHED DATA FOR PENSIONS AND TAX-BENEFIT MODELING

Anna Cristina D'Addio and Herwig Immervoll (2010) 
No. 107 INSTITUTIONAL DETERMINANTS OF WORKER FLOWS: A CROSS-COUNTRY/CROSS-INDUSTRY APPROACH

Andrea Bassanini, Andrea Garnero, Pascal Marianna, Sebastien Martin (2010)

No. 106 RISING YOUTH UNEMPLOYMENT DURING THE CRISIS: HOW TO PREVENT NEGATIVE LONG-TERM CONSEQUENCES ON A GENERATION?

Stefano Scarpetta, Anne Sonnet and Thomas Manfredi (2010)

No. 105 TRENDS IN PENSION ELIGIBILITY AGES AND LIVE EXPECTANCY, 1950-2050

Rafal Chomik and Edward Whitehouse (2010)

No. 104 ISRAELI CHILD POLICY AND OUTCOMES

John Gal, Mimi Ajzenstadt, Asher Ben-Arieh, Roni Holler and Nadine Zielinsky (2010)

No. 103 REFORMING POLICIES ON FOREIGN WORKERS IN ISRAEL

Adriana Kemp (2010)

No. 102 LABOUR MARKET AND SOCIO-ECONOMIC OUTCOMES OF THE ARAB-ISRAELI POPULATION Jack Habib, Judith King, Asaf Ben Shoham, Abraham Wolde-Tsadick and Karen Lasky (2010)

No. 101 TRENDS IN SOUTH AFRICAN INCOME DISTRIBUTION AND POVERTY SINCE THE FALL OF APARTHEID

Murray Leibbrandt, Ingrid Woolard, Arden Finn and Jonathan Argent (2010)

No. 100 MINIMUM-INCOME BENEFITS IN OECD COUNTRIES: POLICY DESIGN, EFFECTIVENESS AND CHALLENGES

Herwig Immervoll (2009)

No. 99 HAPPINESS AND AGE CYCLES - RETURN TO START...? ON THE FUNCTIONAL RELATIONSHIP BETWEEN SUBJECTIVE WELL-BEING AND AGE

Justina A.V. Fischer (2009)

No. 98 ACTIVATION POLICIES IN FINLAND

Nicola Duell, David Grubb and Shruti Singh (2009)

No. 97 CHILDREN OF IMMIGRANTS IN THE LABOUR MARKETS OF EU AND OECD COUNTRIES: AN OVERVIEW

Thomas Liebig and Sarah Widmaier (2009)

A full list of Social, Employment and Migration Working Papers is available at www.oecd.org/els/workingpapers.

Other series of working papers available from the OECD include: OECD Health Working Papers. 


\section{RECENT RELATED OECD PUBLICATIONS:}

OECD EMPLOYMENT OUTLOOK 2013, http://www.oecd.org/els/emp/oecdemploymentoutlook.htm CLOSING THE GENDER GAP: ACT NOW, http://www.oecd.org/gender/closingthegap.htm OECD PENSIONS OUTLOOK 2012, www.oecd.org/finance/privatepensions/ INTERNATIONAL MIGRATION OUTLOOK 2012,www.oecd.org/els/internationalmigrationpoliciesanddatal OECD EMPLOYMENT OUTLOOK 2012, www.oecd.org/employment/employmentpoliciesanddata SICK ON THE JOB: Myths and Realities about Mental Health and Work (2011), www.oecd.org/els/disability DIVIDED WE STAND: Why Inequality Keeps Rising (2011), www.oecd.org/els/social/inequality EQUAL OPPORTUNITIES? The Labour Market Integration of the Children of Immigrants (2010), via OECD Bookshop OECD REVIEWS OF LABOUR MARKET AND SOCIAL POLICIES: ESTONIA (2010), www.oecd.org/els/estonia2010 JOBS FOR YOUTH: GREECE (2010), www.oecd.org/employment/youth JOBS FOR YOUTH: DENMARK (2010), www.oecd.org/employment/youth OECD REVIEWS OF LABOUR MARKET AND SOCIAL POLICIES: ISRAEL (2010), www.oecd.org/els/israel2010

JOBS FOR YOUTH: UNITED STATES (2009), www.oecd.org/employment/youth JOBS FOR YOUTH: POLAND (2009), www.oecd.org/employment/youth OECD EMPLOYMENT OUTLOOK: Tackling the Jobs Crisis (2009), www.oecd.org/els/employmentpoliciesanddata/ DOING BETTER FOR CHILDREN (2009), www.oecd.org/els/social/childwellbeing SOCIETY AT A GLANCE - ASIA/PACIFIC EDITION (2009), www.oecd.org/els/social/indicators/asia OECD REVIEWS OF LABOUR MARKET AND SOCIAL POLICIES: SLOVENIA (2009), www.oecd.org/els/slovenia2009 INTERNATIONAL MIGRATION OUTLOOK: SOPEMI (2010) www.oecd.org/els/migration/imo

PENSIONS AT A GLANCE 2009: Retirement-Income Systems in OECD Countries (2009), www.oecd.org/els/social/pensions/PAG

JOBS FOR YOUTH: FRANCE (2009), www.oecd.org/employment/youth SOCIETY AT A GLANCE 2009 - OECD Social Indicators (2009), www.oecd.org/els/social/indicators/SAG JOBS FOR YOUTH: AUSTRALIA (2009), www.oecd.org/employment/youth OECD REVIEWS OF LABOUR MARKET AND SOCIAL POLICIES: CHILE (2009), www.oecd.org/els/chile2009 PENSIONS AT A GLANCE - SPECIAL EDITION: ASIA/PACIFIC (2009),www.oecd.org/els/social/pensions/PAG SICKNESS, DISABILITY AND WORK: BREAKING THE BARRIERS (VOL. 3) - DENMARK, FINLAND, IRELAND AND THE NETHERLANDS (2008), www.oecd.org/els/disability GROWING UNEQUAL? Income Distribution and Poverty in OECD Countries (2008), www.oecd.org/els/social/inequality 
DELSA/ELSA/WD/SEM(2013)4

JOBS FOR YOUTH: JAPAN (2008), www.oecd.org/employment/youth JOBS FOR YOUTH: NORWAY (2008), www.oecd.org/employment/youth JOBS FOR YOUTH: UNITED KINGDOM (2008), www.oecd.org/employment/youth JOBS FOR YOUTH: CANADA (2008), www.oecd.org/employment/youth JOBS FOR YOUTH: NEW ZEALAND (2008), www.oecd.org/employment/youth JOBS FOR YOUTH: NETHERLANDS (2008), www.oecd.org/employment/youth For a full list, consult the OECD online Bookshop at www.oecd.org/bookshop 